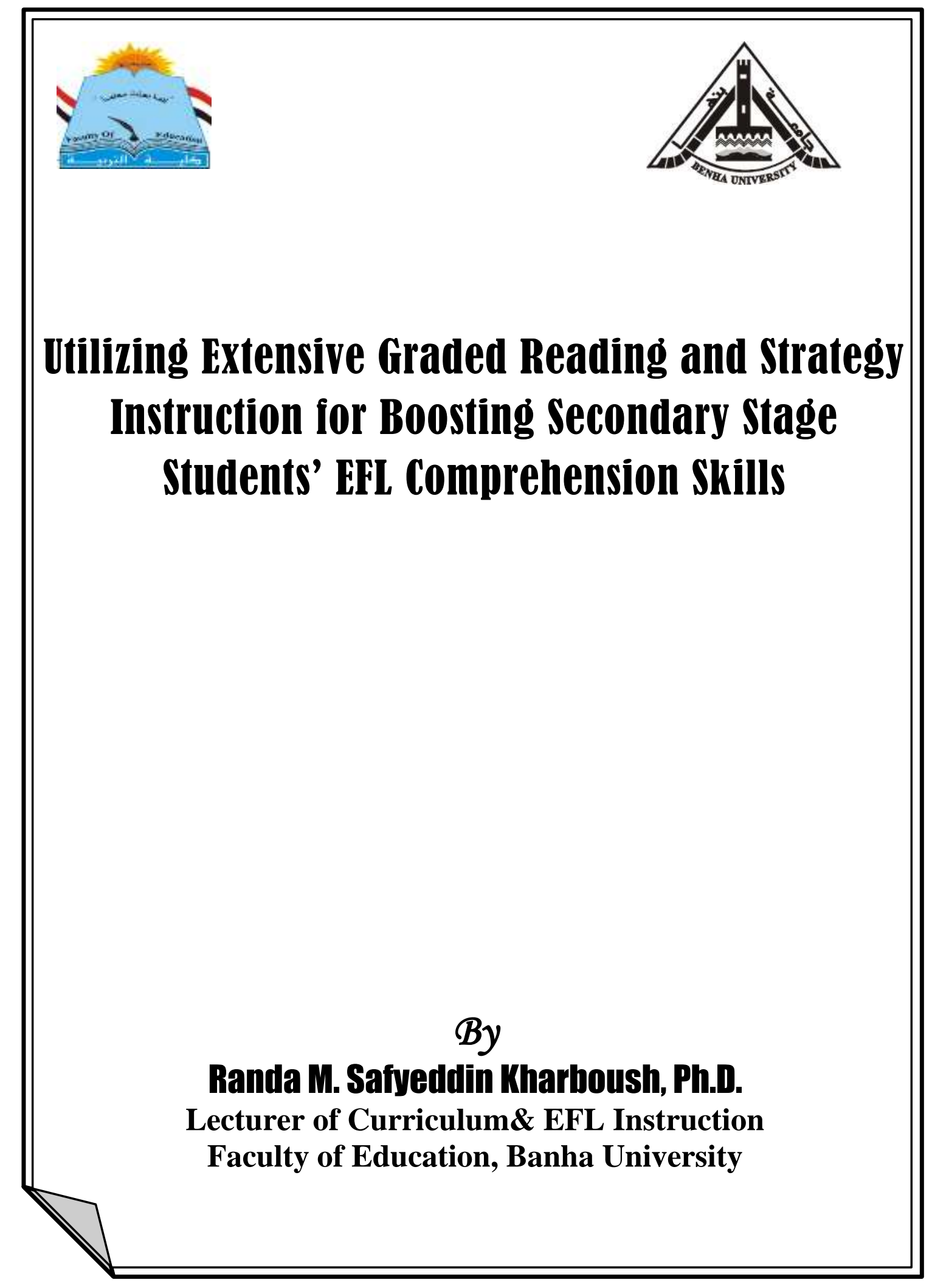




\title{
Utilizing Extensive Graded Reading and Strategy Instruction for Boosting Secondary Stage Students' EFL Comprehension Skills
}

\author{
By \\ Randa M. Safyeddin Kharboush, Ph.D. \\ Lecturer of Curriculum\& EFL Instruction \\ Faculty of Education, Banha University
}

\begin{abstract}
The current study aimed to investigate the impact of utilizing reading strategy instruction (RSI) taught through extensive graded reading (EGR) on Egyptian EFL secondary stage students' comprehension skills. Two first grade EFL secondary stage students $(n=63)$, randomly assigned to two groups, the regular group $(n=31)$ was introduced to EGR for eight weeks, and the intervention group $(n=32)$ received an eight-week experimental intervention of EGR integrated with RSI. The researcher used a quasi-experimental design, and the data collected were statistically treated to compare the two groups and track the effect of the experimental intervention on the participants' comprehension skills. The results of data analysis showed that there was no significant difference between the scores of the two groups in the pre-test, but the mean scores of the post-test for the intervention group was higher than theirs in the pre-test and outperformed the regular group in the post-test. These results were supported by the observation that the researcher had of the participants enthusiastically answering the questions, recycling much of the vocabulary they acquired, and revisiting the grammatical structures they were exposed to through EGR and RSI in the required tasks. The intervention group participants, who experienced EGR integrated with RSI, manifested an improved reading proficiency, enhanced comprehension skills, and expanded use of the taught strategies, particularly glossing strategies, use of contextual clues, and activating background information. Significant results were found on the effect of EGR combined with RSI on improving the participants' comprehension skills. The findings manifested impactful results for participants' employment of the reading strategies after being trained on them during the intervention. The intervention group significantly developed their writing abilities, presented in the open-ended questions, and demonstrated a well-focused writing style. The present study shed light on EFL reading instruction in Egypt and suggested an alternative approach to the traditional ones, and presented some guidelines for instructional procedures that could be used to enhance secondary stage students' EFL comprehension skills, and accelerate their ability to utilize different reading strategies efficiently. The study concluded that the implementation of EGR combined with RSI could have positive effects on EFL students' comprehension skills.
\end{abstract}

Keywords: Graded reading, Extensive reading, Reading comprehension strategy, strategy instruction, comprehension skills.

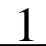




\section{استذامي القراءة المتدرجة الموسعة مه تعليم الاستراتيهيات لتعزيز}

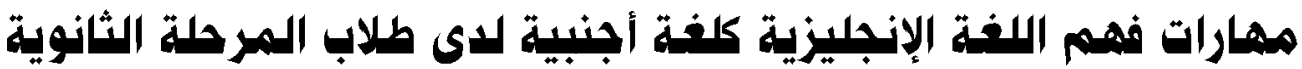

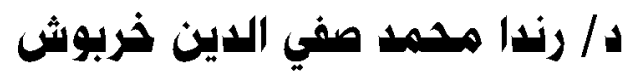

ملدرس المناهج وطرق تلدريس اللفة الإنجليزية

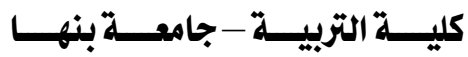

\section{هستخلم ص م}

هدفت الدراسـة الحاليـة إلى دراسـة تأثير تعليم اسـتراتيجيات الفهم القرائي مـن خـلال القراءة

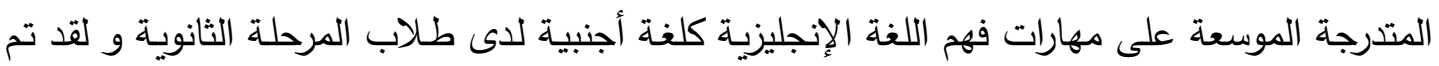

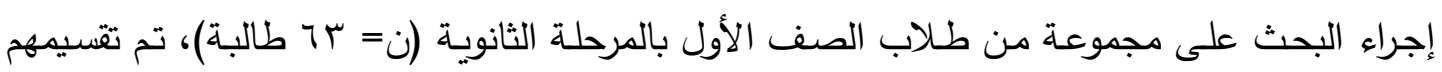

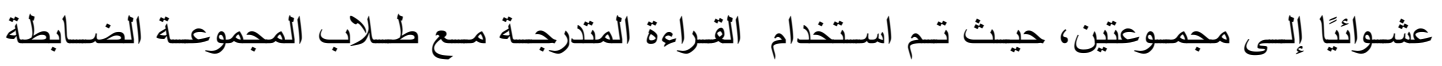

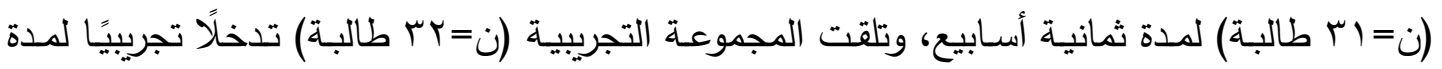
ثمانية أسابيع للتدرب على استراتيجيات الفهم القرائي من خلال القراءة المتدرجة. ولقد استخدمت الباحثة

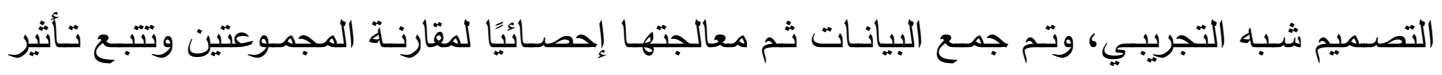

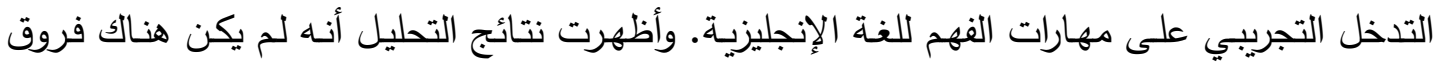
ذات دلالـة إحصـائية بين متوسطي درجات المجموعتين في الاختبار القبلي، ولكن متوسطات درجـة الاختبار البعدي للمجموعة التجريبية كان أعلى من متوسط درجاتهم في الاختبار القبلي، وكذلك تفوقت إتل

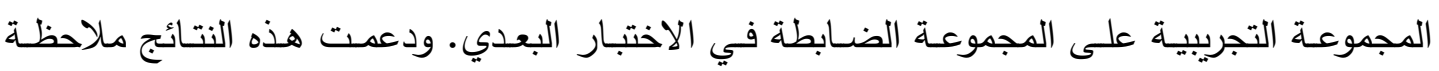
الباحثة للمشاركين في التجربة و حماسهم الملموس للمشاركة في الإجابة عن الأسئلة، وإعادة استخدام الكثير من المفردات اللغويـة التي اكتسبوها، والاستفادة من التراكيب النحويـة التي تعلموها من خلادل القراءة المتدرجة واستراتيجيات الفهم القرائي في إنجاز المهام اللغوية المطلوبة. وقد أظهر المشاركون في لئي

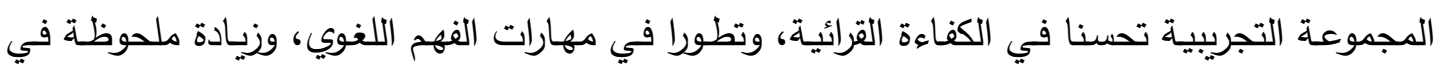

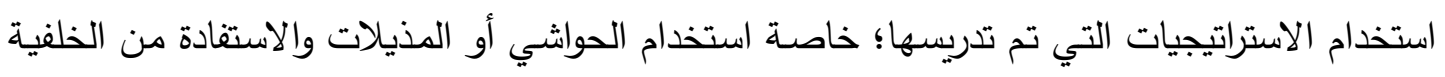

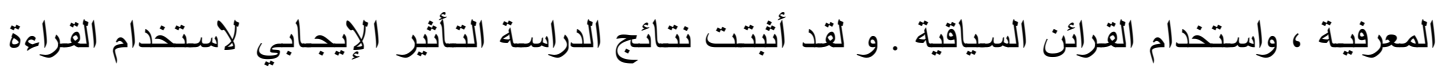

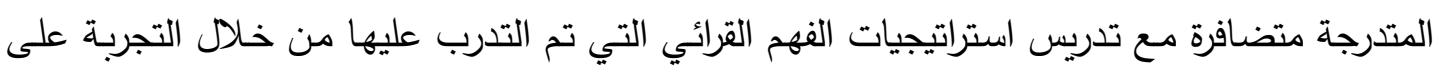

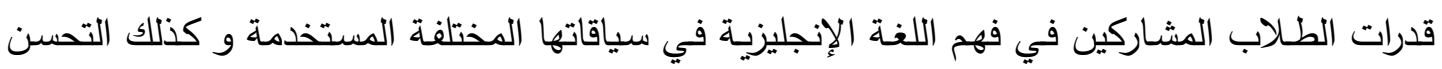
الملحوظ في قدرتهم على التعبير الكتابي التي ظهرت من خلال إجاباتهم على الأسئلة المفتوحة. و ولئه

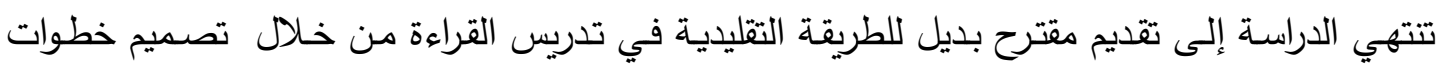
إجرائية تساعد على تحسين و تطوير مهارات الفهم القرائي لدى طلاب المرحلة الثانوية. الكلمــات المفتاحيـةة: القـراءة المتدرجـة، القـراءة الموسـعة، اسـتراتيجيات الفهـم القرائي، تـدريس الاستراتيجيات، مهارات الفهم. 


\section{Introduction}

Reading has been viewed, traditionally, as a collection of discrete sub-skills, each of which could be taught and tested separately. Many modern educational theorists, however, have come to view reading as a whole that is greater than the sum of its parts. According to Anderson (2007), "Reading is a fluent process of readers combining information from a text and their background knowledge to build meaning." Reading is comprehension, and only by emphasizing the process of comprehension will teachers be able to help students to attain a full understanding of what reading means. Students must acquire a repertoire of learning strategies to assist them in dealing effectively with problems in comprehension. Teachers can model, guide, and provide feedback, but students must learn how to apply these strategies to their reading.

Many students approach school reading assignments as something to get through, rather than something to comprehend, integrate, respond to, and extend. They might put time and effort into it, their eyes might browse the words, but they do not learn or remember much of what they read. When learners are engaged in what they are reading, they think about the ideas in the text and try to visualize them, make a connection with their previous experiences and background information, ask themselves questions, analyze the ideas, make inferences, form opinions, come out with predictions to be able to retell or summarize. They construct new understandings and regulate their comprehension to meet their goals and enjoy their reading tasks. Proficient readers keep track of the trail of ideas in the text to make sense out of them, and if they do not understand something, they try to fix up their comprehension; through using the glossary, reading ahead, rereading, or asking the teacher.

Several researchers and educational practitioners claimed that extensive graded reading (EGR) could be an excellent resource for teachers to change the class dynamics, and could significantly improve the language ability and comprehension skills of EFL learners. Through EGR, learners could experience how structures and words function in texts, which might enhance all their language skills and motivate them to use these vocabulary and grammatical structures communicatively. 


\section{Review of related literature}

\section{Extensive graded reading}

Scholars defined EGR as an approach that hooks students in reading long but easy texts, for general understanding, comprehensive meaning, well-established information, and for pleasure as well. EGR in EFL aimed to get students to like the target language through reading. Krashen (2004) claimed that when EFL learners read for pleasure, "they could improve their language skills without even communicating with native speakers, without classes, without teachers, and even without study." Previous researches, (Krashen, 2004, 2013; Lao \& Krashen, 2000; and Smith, 2011), evidenced that EGR could be an effective medium, at suitable levels of EFL instruction, to increase reading rate, enrich vocabulary, teach grammatical structures inductively, promote motivation, enhance comprehension skills, and boost general language proficiency.

In EGR, the target language is graded for vocabulary, the difficulty of grammar structures, as well as the number of words, so it caters for all levels of EFL learners, from beginners through advanced. EFL learners must read at their understanding level because encountering too many unfamiliar words while reading, may cause frustration and discouragement. When learners read at their reading ability level, they have a better chance of developing their reading fluency and furthering their confidence. According to Nation (2001), one of the distinct features of EGR is restricting grammatical structures and vocabulary, which help learners with gaining skills and fluency in reading, promoting previously learned vocabulary and grammar, learning new lexical items and grammatical forms. Accordingly, EGR familiarizes learners with EFL vocabulary and grammatical structures by repetition and recycling, so learners' ability to comprehend any text is significantly promoted, and they are encouraged to read more, consequently improving their comprehension skills.

Graded reading (GR), also known as extensive reading (ER) and the two terms are used alternatively or combined, as extensive graded reading (EGR), throughout the study, is reading long authentic texts that 
may interest the reader. Instead of learning the language as vocabulary and grammar, the focus in EGR is on developing reading fluency and promoting comprehension skills through reading a wide variety of texts. EGR enable learners to progress reading speed, enhance their confidence, enrich their vocabulary, and promote their grammatical knowledge, because, while reading, they revisit unfamiliar vocabulary and grammatical functions repeatedly. Constant repetition of the words and structures allows learners to understand them better and process them faster. EGR exposes learners to massive opportunities to practice the target language, through simplified language and controlled amount of information, to understand more of the text and recycle new vocabulary and grammatical structures systematically and naturally. When reading more through EGR, learners transfer their native language reading skills to the target language and become automatic readers, looking at a text and read the words on it in sequence, subconsciously comprehending what those words mean automatically, without processing or even thinking about them. Automaticity in reading requires a lot of patience and practice to be installed in the memory, but it is highly unlikely to be forgotten.

\section{Principles of extensive graded reading}

As suggested by Bamford and Day (2004), EGR can be explained as a set of the following principles:

Reading materials are easy-Reading for pleasure needs a selection of varied texts with a wide range of topics, to access a wide range of genres that help develop EFL learners' comprehension skills. The variation of reading materials facilitates a flexible approach to reading because learners will read for different reasons, for information, entertainment, or passing the time, using different strategies, skimming, scanning, or reading in-depth, depending on their reading objectives. Learners need to read texts at their reading level, that contain a few new words and no unknown grammatical items. EGR materials have to meet these requirements; otherwise, students will not succeed in EGR because they may struggle with unfamiliar vocabulary and complicated grammatical structures. 
- Reading is for pleasure and information- In EGR, learners read principally for the content of the text, and teachers can ask them about the ideas in the text, their opinion, feelings, and encourage them to speak about it. Commonly, students put off a book when it is connected to an assignment or task or when they feel it is an obligation, but with EGR, the case is different, as reading is for information and pleasure.

Learners read as much as possible- EFL learners can benefit from EGR, mainly because of the quantity of reading, as its materials are not a difficult target for EFL learners.

- Reading speed is fast- EGR is encouraged to improve EFL learners' reading fluency, using strategies that include disregarding unknown words and unfamiliar idioms and encourages guessing their meaning from the context. Using dictionaries during reading is very disturbing; however, if a word appears in a text several times and seems to be essential for further understanding, the learner should be allowed to seek its meaning in the glossary. Nevertheless, when a word appears just once, and its meaning is not critical in understanding the text, learners can ignore it. The advanced learner who read more challenging texts can mark the words they do not know and continue with reading without any interruption if they can comprehend the general idea, and later on, they can look them up in the glossary or the dictionary.

- Reading is a reward- The goal of EGR is to enrich learners' experience, often followed by comprehension questions, or follow-up activities; to find out what the learners understood from the text, to keep track of what they read, to check their viewpoints and attitudes, and to encourage further readings.

- The teacher's role is to orient and guide the learner- EGR differs from traditional classroom reading practice in many ways. Teachers need to explain to the learners what the term EGR stands for, reasons for doing it, how it works, what benefits they can get out of it, and guide them to get the utmost benefits and enjoyment out of their reading. 
- The teacher is a role model- The teacher has to share reading what learners read and consequently participate in discussions with them, which might give learners a model of what it is to be a reader. It also helps to create a reading community where the teacher and learners experience together with the value and pleasure of EGR.

\section{Using extensive graded reading for language development}

EFL researchers since the 1980s and 1990s (Adams, 1990, Elley, 1991, Hafiz \& Tudor, 1989, 1990, Hayashi, 1999, Mason \& Krashen, 1997; Nagy, 1997, Nagy \& Anderson, 1984, Nagy, Herman, \& Anderson, 1985, Robb \& Susser, 1989, Tsang, 1996 and Walker, 1997 in Day, 2011) recognized EGR as an effective procedure for encouraging language growth, vocabulary acquisition, and retention and improving reading comprehension. They asserted that EGR enhanced learners' listening and speaking skills, increased their lexical knowledge, developed not only their vocabulary knowledge but also improve their writing, listening, and speaking skills. Elley and Mangubhai (1981) claimed that ER played an essential role in developing students' listening and writing skills, and Tsang (1996) argued that it helped in promoting learners' writing proficiency. Waring \&Takaki (2003) found that EGR contributed to vocabulary development, followed by Horst (2005), who also confirmed that ER resulted in increasing learners' vocabulary. Takase (2007) stated that EGR promoted learners' motivation, and Iwahori (2008) reported that the ER had a noticeable impact on his Japanese students' language proficiency and increased their reading rate.

There is a robust literature that has reported EGR's influence on language learning. Many experimental and quasi-experimental studies demonstrated the effectiveness of EGR in increasing reading rate and fluency, promoting attitude and motivation, and enhancing other language skills (Bamford and Day, 2004; Krashen, 2004; Nation, 2001). EFL learners who read extensively gained overall language proficiency, as it developed their vocabulary knowledge and grammatical structures, which provided them with many opportunities to promote their writing, listening, and speaking skills. Besides, EGR significantly allowed numerous chances for exposures to new words and structures that EFL 
learners might repeatedly recycle, which enhances their language knowledge. As learners understood the target language better, they developed positive attitudes and increased motivation towards language learning. EGR can provide excellent opportunities for EFL learners to revise what they have done in class by using the learned strategies in reading lots of simple text at their reading ability level. A massive advantage of using EGR is that it does not take up much class-time because the reading practice can be done out of class.

Recent studies (Burrows, 2012; Cheetham 2018; Mardiana \& Hidayat, 2019; Waring, 2012) claimed that the amount of vocabulary and grammar that learners study is not the only determiners of their language proficiency anymore. EGR enables learners to attain competencies in language skills and enhance their comprehension skills, as it empowers them to practice reading skills, providing multiple chances to reinforce known vocabulary and structures. Through the multiple opportunities of exposure to the target language, EFL learners develop their comprehension skills, moving from the surface, literal level of the text, to the inferential, interpretive, between -the lines- level, reaching the applied, beyond -the text- level. They gain reading fluency, enhance their vocabulary, develop their grammatical knowledge, experience how to function in different texts, and to use the vocabulary and structures they have learned in communication.

The research demonstrated that learners made gains in overall language proficiency by EGR, (Hook \& Jones, 2004; Ostovar-Namaghi, 2018; Wolf, 2018) proved that EGR increased reading speed and proficiency through increasing the level of automaticity. When students read in their native language, they often read whole 'chunks' of words together, and the more familiar the words are, the faster they read because they automatically recognize what they see, and do not have to process it. Many learners, when reading EFL, they use their index finger to move from one word to another, and they do not 'automatically' recognize vocabulary, which can noticeably slow down their reading. By the time they get to the end of a paragraph, they may have forgotten what they read at the beginning. Their level of automaticity is low, which can even prevent comprehension of the text as a whole. 
A growing amount of research (Bakeer, 20018; Kirin, 2010; Mermelstein, 2015; Yamashita, 2008) proved that using EGR over an extended period can have a positive influence on other language skills, mainly when it was supported by constructive feedback and motivation throughout reading activities. This process assisted learners in improving their writing skills; to produce better-written work, and be more willing to experiment with the acquired vocabulary and linguistic forms. Kirin (2010) conducted a fifteen-week reading experiment with a group of low proficient Thai EFL learners to attain the effects of EGR, through reading simplified books, on their reading and writing abilities. All the participants had their essay writing abilities measured periodically, every five weeks, throughout the experiment. Research results provided evidence those low-ability readers, who could not read large amounts, did not improve writing abilities. Mermelstein (2015), in his study, focused on using EGR for improving learners' writing abilities. He used writing measurement, including content, vocabulary, language use, organization, and mechanics, for pre/post tests. The results indicated significant differences in favor of the treatment group. Along the same line, EGR was effective, according to Bakeer (2018), in developing students' performance in writing and producing clear, coherent language, as it provided them with many opportunities to experience new vocabulary and structure and their uses in context.

Research showed that EFL learners need to meet language features many times to learn them, as the brain does not learn things all in one time, and language needs to be learned in small pieces rather than as whole chunks. Waring (2012) claims that all these factors that learners need are available with EGR, where readers are going to deepen their knowledge, recycle words, and revisit grammatical structures. EGR focuses on several skills but, most importantly, on comprehension, through reading massive amounts of comprehensible language in their comfort zone to build fluency. Reading a lot of authentic longer texts in EGR allows the learner to affiliate language 'usage' with its actual 'use.' According to Waring (2012), EGR is one of the best ways in which learners can get access to language at its natural context, read something 
they want to read, at their own pace, and within their comfort level. EGR allows them to meet the vocabulary that is recycled and the grammatical structures that are revisited enough times to pick up a sense of how language works in use.

Elliott and Cheetham (2018) claimed that the driving force behind including EGR in any EFL curriculum is to get students to read more and become self-actuated autonomous learners by making reading a habit, but for the most part, EGR approaches rely on learners to be highly motivated (Kirchhoff, 2013). Accordingly, the instruction requires a significant effort to motivate students to achieve reasonable success. Teachers can promote learners' motivation by including opportunities for competition and reward, and through their autonomy and collaboration (Grabe \& Stoller, 2011). Teachers can nurture EGR habits and create and foster a 'learner community' (Shibata, 2016), in which students can get support, share their experiences, and get information on EGR. Mardiana\& Hidayat (2019) explored the effect of extensive reading on senior high school students' reading achievement. They used extensive reading as an alternative method in teaching reading to $27 \mathrm{high}$ school senior students. The results showed that the mean score of the posttest was higher than pretest in experimental class that used extensive reading, which had positive effects on the students who were quickly understanding the meaning of the text, enthusiastically answering the questions, acquiring much new vocabulary, having fun, and enjoying being actively involved in the instruction process.

\section{Extensive graded reading instruction guides}

The reading guides are designed to assist the reader's thinking process. They differ from conventional textbook exercises in, when, and why they are used. They are generally used before reading as well as after reading. The reading strategy instruction guides (Appendix 7) are oriented more towards the process rather than the product of reading, which can boost learners' comprehension skills. They are intended to be with the reader along the way to coach and support the process of thoughtful reading. Guides can be categorized into three levels, depending on their purposes. According to Nation (2009), guides can be 
combined or adapted according to the type of reading materials and the needs of the students. The following section will provide a summary of the purposes, rationale, and functions of the essential guides reported in the literature (Akhavan, 2014; Forresy-Pressley et al. 2013; Otto \& White, 2014; Tzeng \& Singer, 2017).

\section{A- Guides that promote skills and develop strategies}

- Processes of Reading Guide - Akhavan (2014) claimed that the various processes involved in the act of reading could be taught via the processes of reading guide that helps students through the entire text, beginning with modeling the skill; using cause and effect, sequencing, drawing conclusions, predicting outcomes, examples and practice items. Then, students get back to the text for the application of the skill or the process learned.

Text connection guide- Draper (2012) asserts that comprehension is 'making meaning' of texts, including print, auditory, visual, digital, or multimedia kinds of text. Students encounter difficulty in comprehending when they lack reading comprehension strategies, background knowledge of the topic, including vocabulary, structures, and other features of the text, and a purpose for reading the text and engaging in it. Making connections is a strategy that can assist in making meaning from a text. Students can make connections between text and self, text and text, and text and world. This guide includes text structure questions, which are used as introductory, definition, transitional, illustrative, summary, main idea or supporting details, chronological order, compare-contrast, cause-effect, problemsolution, descriptive, or narrative.

- The Process Guide- (Kintsch, 2005) claimed that the process guide was designed to help students identify the skills necessary to understand specific content. It is an atypical guide, as it is printed on strips of paper to be lined up with the text. A process guide can include several skill areas, such as paragraph structure, context clues, inferences, interpretation, and evaluation. This kind of guide focuses on how to deal with the text, as it aids the students through the 
reading process and assists them in processing the information and concepts. Process guides scaffold students' comprehension within non-traditional formats and designed to stimulate readers' thinking during and after reading. Process guides prompt thinking, ranging from simple recall of relevant information and ideas to connecting information and ideas to prior experience and background information, applying new knowledge for problem-solving, and making their reading more efficient.

\section{B- Guides that Facilitate Content Understanding}

The three-level reading guide-This reading guide is based on the idea of defining reading comprehension as a three-level process involving literal, interpretive, and applied comprehension. Fountas and Pinnell (2005) adopted the idea as the basis of their landmark in the field, going from the literal level of understanding to the interpretive and applied levels, and generating meaningful uses of information to develop comprehension skills. This guide is characterized by using declarative statements instead of questions to guide students through the process, and the students must determine the appropriateness and logic of each statement and find support for it in the text. The teacher writes a series of statements about the text, some are true, and some others are false, and the students are asked to agree or disagree with these statements and justify their responses, which encourages students to read the text carefully by providing a clear purpose and direction for reading. Then, they can share their answers and discuss their points of view on the issues explored in the text, based on the information gained, to resolve their disagreements and reach a consensus.

Concept Guide - Concept guides are designed to assist students in categorizing subordinate information and associating them with the main idea. Literal level tasks comprise the first step of the concept guide, then in the second step, students must relate the details in the text to the main concept, and the final step involves a higher level of comprehension in which students are required to support the main concepts with details from the text. 


\section{Guides with dual purposes}

Glossing - Otto et al. (1981) are credited with demonstrating the use of marginal notations or glossaries and its role in improving texts' comprehension. They have shown how glossing can be used to help readers: develop a purpose, set a strategy, use their prior knowledge while reading, and attend to the external and internal organization of a passage or to help monitor comprehension. Glossing can be used to direct students' attention as they read to essential vocabulary and idioms, and can be developed to focus on the reading process itself; skills, strategies, or content. According to the results of many empirical studies, Abdullah, Heng, \& Hoon (2012); Al-Jabri (2009); Arpac1 (2016); Danesh\& Farvardin (2016); Dehdari \& Sadeghoghlo (2018); Farvardin \& Biria (2012); Gan (2014); Hong (2010); Ko (2005); Liu (2011); and Teng (2019), glossing promotes the target language comprehension and facilitates vocabulary learning. It helps to limit dictionary consultation that may interrupt the reading process and contributes to consciousness-raising. It also reinforces form-tomeaning connections. Marginal glosses are easier to use than a dictionary.

Guide-O-Rama- The Guide-O-Rama was developed to help students learn "not only what to look for but what to do with it when they find it." Guide -O-Rama is a set of prompts that help the students to read and think about the text, and it does not necessarily require a written response. In this guide, teachers begin by eliminating any sections of the text that do not help achieve the overall purpose for reading. The guide-O-Rama includes directives to govern the speed at which students read since it varies between proficient readers and less able ones. Such directives are designed to develop flexibility in reading rate and to teach students to skip over the unimportant details or read quickly through material that is not significant.

Interactive reading guide - While most guides were initially designed for students to work alone while responding to a series of questions, this interactive guide is based on requiring responses from individuals, pairs, small groups, or the whole class. Consequently, 
unlike most guides, it is an in-class strategy that may require students to make predictions and come up with conclusions.

- Graphic Organizers- Graphic Organizers can function as a form of a study guide, as they are quick, straightforward, easy to make, and they provide an excellent visual asset for students who need more nonverbal input, and they prescribe a structure for note-taking. Graphic organizers require students to stop reading and think about what is important in the part they read and display information to the pictorial form or a writing assignment as something tangible to complete. Graphic organizer formats can be used alone or in combination with other reading guide formats, to give concrete forms to the abstract structured patterns of texts.

\section{Reading strategy instruction (RSI)}

Many researchers recognized the importance of reading strategies for EFL learners and several investigations have been conducted to examine the relationship between using reading strategy and improving different language skills (Barnett, 1988 in Barrot, 2016; Block, 1986, 1992; Carrell, 1989; Dole, Duffy, Roehler, and Pearson, 1991; Hosenfeld, 1976, 1977; Irwin\& Baker, 1989; Knight, Padron and Waxman, 1985 in Cheng, 2003). Many of them, since the 1980s and 1990s, have shown that reading strategy instruction is effective in enhancing comprehension skills as well (Anderson, 1991; Carrell, Pharis, and Liberto, 1989; Carrell, 1998; Janzen \& Stoller, 1998; Loranger, 1997; Paris, Lipson, and Wixson, 1983; Song, 1998; Sun, 2011; Tierney, Readence, and Dishner, 1995 in Burrows, 2012).

More recently, several researchers started to examine EFL learners' need for reading strategy instruction. For instance, Al-Nujaidi (2003) investigated the relationship between vocabulary size, reading strategies, and reading comprehension of EFL learners in Saudi Arabia. The results indicated that all participants, 226 university EFL students reported using reading strategies. However, only those with larger vocabulary size and higher reading proficiency used a variety of reading strategies, which proved that there is a correlation between higher levels of reading proficiency and increased use of reading strategies. Taylor et 
al. (2006) conducted an analytical study to investigate the effect of reading strategy instruction on reading proficiency. They found that EFL learners who received explicit RSI could comprehend texts in the target language surpassed those that did not receive such instruction, which proved that RSI could have a positive effect on EFL learners' reading proficiency.

\section{Guidelines for reading strategy instruction}

According to Bogale (2018), Brevik (2019), \& Yu-Ju (2014), comprehension is viewed as a much more complex process, involving knowledge, experience, thinking, and teaching. The following guidelines for comprehension instruction can be used:

1- Focus on the process of comprehension and move towards independent learning. The goal of instruction should be to improve the students' abilities to comprehend the text without the teacher's assistance. The emphasis during instruction should be on enhancing the students' ability to use comprehension strategies independently, on their own. The focus should be on the process of developing a true understanding of comprehension within the students, not merely the product of passing the test. Teachers should model the strategy and provide guided practice opportunities for the students, and gradually turn the responsibility of completing the task over to the students who should make the application in which they transfer and use what they learned to new reading texts. This scaffolding process helps students and encourages them to use the strategy on their own.

2- Provide ample time for reading. Teachers can provide the students with chances to increase their comprehension through silent reading, group reading, thinking aloud, and more, which results in the acquisition of new knowledge that, in turn, helps them in their future reading experiences. EGR can assist the students in developing their fluency and confidence in reading, encouraging them to read increasingly longer authentic texts, which can help them enrich their vocabulary and develop their ability to figure out the meanings of new vocabulary. 
3- Provide opportunities to learn collaboratively and talk about reading. When students have the chance to talk about their reading with each other, they incorporate their viewpoints and elaborate on their understanding and learn about their peers' used strategies to comprehend the text. Additionally, when students share their impressions, interpretations, and reactions to the reading text with the teacher and their peers, the conversation creates limitless opportunities for constructive interaction and autonomous learning.

4- Facilitate comprehension instruction before, during, and after reading. Building background information and activating prior knowledge before reading is as equally important as teaching students to be actively involved during reading. After reading, students should be taught how to organize the gained information and relate them to their background knowledge to be able to retrieve them later for application and use with new settings.

5- Think aloud. Think-aloud can be beneficial for EFL learners to acquire vocabulary-learning strategies, understand text structure, enhance their comprehension, and promote higher levels thinking skills. Comprehension strategies can be illustrated and demonstrated by the teacher, and sharing their reasoning processes with the students is very beneficial. It is helpful for the students to stop periodically while reading the text, reflect on what they are reading, verbalize their thinking processes, and relate orally, with teacher and peers, to the reading strategies they have employed to comprehend the text. Think-aloud can also be used to assess comprehension while students are working in pairs or small groups.

6- Reinforce and develop reading abilities through writing. Writing instruction can generally enhance reading development and vice versa. Students should be taught 'to read like a writer' (Skeans, 2000), and to understand the value of writing as a process of reflection, which improves their critical thinking. Proficient reading with comprehension, according to Gunther (2000), involves "establishing relationships between the text and the schema of the reader, which promotes the ability to organize and relate information in an understandable manner, the same generative skills that are 
needed for effective writing." Competent writers are usually proficient readers; they tend to read more and produce more mature writing than struggling readers. By pairing writing tasks with reading ones, teachers reinforce reading through writing and augment writing through reading across the curriculum, which facilitates students' literacy ability.

7- Assist students in using visual information to comprehend text. The definition of literacy includes comprehending visual information, which involves the ability to interpret visual information such as pictures, charts, and diagrams in the text. Researchers (Gambrell\& Brooks-Jawitz, 1993; Purnell\& Solman, 1991in Day, 2011) found that pairing meaningful visual information with text assists students with comprehension and retention of information and vocabulary.

8- Make assessment compatible with the kinds of learning encouraged. Assessment can be folded into instructional activities, asking students to demonstrate their understanding of content. When comprehension assessment becomes a seamless activity with instruction, students can document their growth in reading comprehension across a variety of texts. Answering higher-order questions and using analogies give students the means to demonstrate and apply the skills they have learned. They go beyond the literal level of understanding to deeper engagement with the text.

EFL reading curriculum should aim to maintain a well-balanced instruction that provides equal time for 'meaning-focused input, meaning-focused output, language-focused learning, and fluency development' (Nation, 2009). In many EFL contexts, including the Egyptian EFL secondary classroom, meaning-focused input and fluency development are often ignored to save more time for language-focused learning. According to Nation (2001), EGR provides learners with a greater balance of meaning-focused input, language-focused learning, and fluency development. Nation and Webb (2011) argued that even though many studies proved the benefits of EGR, there were few action research and classroom-based studies conducted by teachers assessing its effectiveness. Many teachers are reluctant to incorporate EGR into their 
English reading curriculum because they believe that students may not have the motivation or willingness to complete the reading, especially the authentic longer ones. Takase (2007) suggested that teachers might overcome such reluctance by setting up EGR activities related to the text that could take place in the classroom, then students would be engaged in reading, and might be more willing to continue reading with enthusiasm.

\section{Using extensive graded reading (EGR) with reading strategy instruction (RSI)}

Cheng's (2003) conducted a quasi-experimental with Taiwanese EFL first-year university students in two classes to experiment using an integrated ER and reading strategies. Results showed that the group that received ER plus word-guessing strategy instruction outperformed the other group, which received ER plus L1 translations of unknown vocabulary. Additionally, analyzing the data of the group that was trained on using the reading strategy approach indicated that higherproficiency readers benefited more from the strategy instruction than lower-proficiency readers. Researchers continued their endeavor to offer a well-balanced language learning environment for EFL students. Burrows's (2012) dissertation study went more in-depth into analyzing the effects of RSI in combination with EGR on reading self-efficacy among EFL learners by investigating the difference in learning outcomes. The participants $(\mathrm{N}=322)$ were divided into four groups: an intensive reading group as the control group, then the other three as experimental groups, an EGR group; a reading strategies group; and an EGR with reading strategies. Results indicated that the learners in the RSI group and RSI/ EGR group gained significantly in reading selfefficacy, and all three experimental groups' participants outperformed those participants in the intensive reading group.

Elghotmy (2018) investigated the effect of sheltered instruction strategies on developing EFL first-year secondary stage students' reading comprehension skills. Seventy EFL first-year secondary stage students were randomly assigned into two groups; experimental $(n=35)$ and control $(n=35)$. The experimental group used sheltered reading instruction strategies, while the control group went through regular 
reading instruction. The findings indicated that EFL first-year secondary stage students of the experimental group outperformed those of the control group in their EFL reading comprehension skills. Later, Alsofyani (2019), in her study, tested the impact of metacognitive strategies, discussion, and collaborative learning on EFL Learners' reading comprehension using multimedia E-book dialogic environments. She explored how Saudi EFL college-level learners might better tackle reading comprehension challenges by utilizing metacognitive strategybased discussion and collaborative learning.

Additionally, the study investigated the effectiveness of the multimedia e-book environment on the participants $(\mathrm{N}=115)$ overall reading comprehension. A mixed-methods quantitative-qualitative approach was employed. The findings showed significant effects of the metacognitive strategy-based discussion and collaborative on learners' reading comprehension. The qualitative findings revealed that the metacognitive strategy -based discussion and collaborative learning were beneficial for EFL students in improving focus on the text, use of strategies, comprehension, and reading performance.

\section{Comprehension model}

Irvin et al. (2007) developed a comprehension model that described the thinking processes and comprehension strategies, which can co-occur, that readers use before, during, and after reading. Struggling readers often feel frustrated and give up when they do not understand the text. Helping those readers by providing them with such learning strategies and modeling when and how to benefit from them, give them a mine of essential tools that help them to become independent readers and autonomous learners. Factors central to these strategies are instruction in prior knowledge, text structure, and the context that enables readers to comprehend the text more proficiently. The thinking processes and comprehension strategies occur along the following lines:

- To activate background knowledge and preset a purpose for reading- Before reading, readers activate what they know about 
the topic by looking at the title, glossary, graphics, and other visuals. They might skim the text for main ideas and think about expected questions or tasks to be requested after reading the text: writing a report, explaining a concept, or applying the gained information in a different setting.

- To organize knowledge- During and after reading, readers summarize the main ideas and restate them in their own words. They might skim through the text and reread parts of it to create their concept map, write a summary, create an outline, or take notes. This process can help student-readers to understand, remember, and recycle the ideas, concepts, and even the vocabulary presented in the text.

- To make inferences- Readers make inferences throughout their reading, connecting their prior experiences and using their background information with what is in the text. The inferencemaking process facilitates the text's comprehension.

- To visualize,- Readers must analyze and interpret visual information presented in the text. Students today are bombarded with visual information in all forms. Having visual information, whether pictures, charts, diagrams, or other visual representation assists readers to use their imagination to create pictures or concept maps in their mind.

- To figure out the meanings of unknown, unfamiliar words- As students read increasingly longer authentic texts, they naturally encounter words they do not know. Reviewing text for keywords and using structural clues and contextual ones can help them to increase their vocabulary and comprehend the text. Vocabulary knowledge is strongly related to comprehension because understanding words enable readers to understand the text, and vocabulary plays an influential role in language comprehension and production as well.

- To ask questions- Through the reading process, students ask themselves questions about the text, their previous knowledge 
about the topic, the concepts and ideas in the text, and try to figure out answers for these questions, which indicate that they are thinking about the reading and connecting with the ideas in the text and trying to relate them to their background information and prior experiences.

- Figure out what is important to know- To comprehend a text, readers must identify, remember, summarize, and synthesize the main ideas presented in the text. Taking notes, constructing concept maps, creating an outline, and asking questions to help readers to identify what is significant to know in the text.

\section{Comprehension strategy instruction}

According to Irvin et al. (2007), comprehension strategies (Appendix 7), are presented in four categories: teacher-guided activities that facilitate comprehension before, during, and after reading; comprehension-monitoring activities; study guides; and graphic organizers.

Teacher-guided strategies- These strategies provide teachers with opportunities to model thinking processes for the students and guide them through processing their thoughts. All strategies have a before, during, and after reading component for facilitating comprehension.

Reciprocal teaching- Reciprocal teaching is a dialogue between teacher and students using four strategies: questioning, summarizing, clarifying, and predicting. Teachers should guide students through this process, helping them to generate the right questions, create a summarized version of the text, and make predictions based on the text. Teachers and students take turns talking to each other, individually and or in groups, about all components of the text, which provides opportunities for teacher's modeling and guidance and students' independence and eventually turning into autonomous learners. Reciprocal teaching can be a powerful tool for assisting students in understanding and internalizing the comprehension process through active involvement. 
M- $W$ - $L$ - The K-W-L strategy is a powerful yet simple to use procedure that provides an organization to students learning. It engages students in making a connection between their prior knowledge about the text $(\mathrm{K})$, self -questioning to fill in their information gap (W), and determining the importance of what they learned during reading (L). This strategy has been successfully used in high school classrooms and has been found to improve comprehension monitoring, and provide opportunities to involve students in the learning process before, during, and after reading.

- Comprehension monitoring strategies - Students have to monitor their comprehension to become eventually autonomous learners. These strategies are designed to help students using metacognitive processes proficiently. A self-monitoring approach to reading and thinking (SMART) is a strategy that can assist students in identifying what they understand and what they do not in their reading.

- Paired reading- Paired readings is another strategy that aims at improving reading fluency and comprehension in which students are paired and take turns, one reads, and the other follows along, or to read together simultaneously; both read out loud together. With the assumption that two heads are better than one, (Cassidy, 2007; Fuchs, 2000; and Gerdes, 2000) suggested that paired reading can be a means for helping students to learn, maintain and recycle more of what they have learned.

\section{EFL reading in the Egyptian secondary stage}

It is crucial to understand how reading is often taught in Egyptian classrooms with its standard reading text and tasks given to Egyptian EFL learners. According to the strategic plan for pre-university education reform in Egypt 2014-2030, students must be able to use English for social purposes, and the focus of language instruction is on functional, communicative English, with emphasis on all four language skills. These principles have been applied in the series of textbooks Hello!, for Secondary Schools, for 1st through 3rd grades. The focus is supposed to be on critical thinking skills and strategies to improve language and learning skills, which can produce more autonomous learners. Student-to-student interaction and working together cooperatively, in pairs and groups when asked, have a permanent place 
to encourage them to develop a sense of independence and responsibility for their learning to become autonomous learners.

However, rote learning still receives more acceptance and encouragement in Egypt by teachers, parents, and students. Unfortunately, English teachers in Egyptian secondary schools, have only five lessons per week, 40- to 45-minute each. There is no enough time for critical thinking and reading tasks, and writing tasks are assigned for homework. Based on classroom observations, Abdel Latif (2012) found that grammar and vocabulary were allocated over twothirds of class time $(70.08 \%)$ with listening, speaking, and writing accounting for barely four minutes in a lesson. In reality, on the ground, teachers frequently focused on grammar and vocabulary regardless of the lesson type. The main concern is about language 'usage,' which involves knowledge of linguistic rules, rather than its 'use' that means knowing how to use these rules for effective communication.

\section{Context of the problem}

To verify the study problem, the researcher interviewed some EFL secondary stage teachers and attended some of their classes for observation. The common beliefs about successful teachers are generally the ones who teach students as many words as possible in one class and help them understand grammar rules correctly. The researcher observed that most teachers are falling into some mistakes, such as ignoring inductive grammar activities in the textbook, and explaining grammatical rules using the board, and focusing only on grammar and vocabulary, even in the warming-up stage. They also change reading lessons into vocabulary lessons, and transform listening and critical thinking lessons into vocabulary lessons. They frequently check students' grammar and vocabulary knowledge, which is their primary concern, or explain grammatical rules or meaning of new words and their derivatives, synonyms, and antonyms, using Arabic translation most of the time. Moreover, the new programs that aim to use EGR as a method to encourage language growth are not followed thoroughly. 
EFL secondary stage students are studying the usage of the English language rather than learning to use it. Learning to use a language does not only mean to be able to communicate fluently in various situations but also be able to read or listen without any significant problems. The most recent studies, Ahmed, 2019; Badawi, 2019; Elghotmy, 2018; and Ibrahim \& Ibrahim, 2017, indicated that EFL secondary stage students in Egypt have an inadequacy in their comprehension skills and they face many difficulties in reading longer authentic texts. Many of them assured that Arabic was the dominant language used in most of the classes observed, and probably in most English classes in Egypt. English was not used for any real communication; the language used by teachers and students was restricted to reading the textbook and answering the drills. Reading is still taught using traditional strategies that are not promoting learners' comprehension skills.

Most of the teachers, during the interviews, agreed that EFL firstyear secondary stage students suffer from weakness in their reading comprehension and face many challenges, especially with longer authentic reading text, such as the assigned story of Oliver Twist. For many students, it is an intimidating task, because they are introduced to unfamiliar vocabulary and the language presented is, sometimes, beyond their level, which makes understanding that text very difficult, and they have to stop now and then to look up unknown words in the dictionary. The researcher also documented the problem by administering a prequestionnaire (Appendix 1), and a pilot reading comprehension test (Appendix 2) on sixty-three students and the results, the mean score of 15.58, and Std. Deviation of 4.89, indicated that there was a noticeable deficiency in their reading comprehension.

Previous research verified many benefits coming from EGR and attested its effective contribution to acquiring, extending, and recycling a foreign language (Bamford and Day, 2004; Hill, 2008; Krashen, 2004; Nation, 2001; Waring, 2012). Besides, several studies, Al-Nujaidi, 2003; Alsofyani, 2019; Burrow, 2012; Chang, 2003; Elghotmy, 2018; Sun, 2011; and Taylor et al., 2006, claimed the effectiveness of RSI in developing and even improving, EFL learners' comprehension skills. 
In conclusion, based on the review of previous studies, it could be claimed that introducing EGR combined with training students on using RSI might help to boost their comprehension skills. Integrating RSI with EGR could furnish more opportunities for a successful language learning curriculum, providing EFL learners with a well-balanced meaningfocused input, language-focused learning, and skills development.

\section{Statement of the problem}

Based on review of previous related studies, researcher's observations and interviews with EFL secondary stage teachers, results of the pre-questionnaire and preliminary pilot reading comprehension test, it can be stated that many EFL secondary stage students suffered from difficulties in reading and comprehending English texts and they have a lot of trouble in getting the main ideas and subordinate ones, collecting details or information, answering the questions, guessing the meaning of unknown words, because the teachers were, likely, using their native language (Arabic) to explain what the students could not understand.

\section{Aim of the study}

This study aimed to boost secondary stage students' EFL comprehension skills through a balanced reading approach that incorporates EGR with RSI. The suggested approach would help the students to read confidently and fluently, to read at their ability and comfort level, emphasizing EGR's contributions to their comprehension, and stressing the role RSI could play in EFL skills development.

\section{Study questions}

The following main research question was addressed:

( How far does extensive graded reading integrated with strategy instruction affect EFL comprehension skills of secondary stage students?

The following sub-questions emerged from the main one:

- To what extent does extensive graded reading affect secondary stage students' EFL reading proficiency? 
- To what degree does reading strategy instruction affect secondary stage students' EFL comprehension skills?

- What is the effect of integrating extensive graded reading with reading strategy instruction on secondary stage students' EFL comprehension skills?

\section{Method of the study}

The design in this study was a pre/post-test quasi-experimental, with two groups of participants.

\section{Participants}

The participants were sixty-three students of first grade in ElSadat secondary school for girls in Benha directorate, Qualyubia governorate, Egypt. The participants of the study were randomly assigned based on availability and convenience. The participants' native language was Arabic, and they have been learning English as a foreign language (EFL) for at least ten years. Those students are assigned to have five lessons of EFL per week, 40- to 45-minute each, one of them was supposed to be for the reader. The intervention group $(n=32)$ was taught using EGR integrated with RSI, whereas the traditional group $(n=31)$ studied EGR using regular instruction. The researcher taught both groups.

\section{Instruments}

The researcher used the following instruments for collecting the research data:

- A pre-questionnaire (Appendix1) to get the students' opinions ( $\mathrm{N}=63$ ) about reading in English, and the kind of challenges they face in reading English texts. The pre-questionnaire consisted of ten questions with three response options; 'Yes,' 'Sometimes,' and 'No.'

- A reading comprehension preliminary pilot-test, adapted from SRA Reading laboratory 1b, (Appendix 2) was administered to document the study problem and to determine the entry-level of the participants, to guarantee their homogeneity. 
- Two versions of Oxford graded reader tests, level 6, were administered to evaluate the participants' comprehension skills, version (1) for pretest (Appendix 3), and version (2) for posttest (Appendix 4).

- A reading strategies questionnaire consisting of 20 items on a 5-point Likert scale, adapted from Tsai's (2000), for the current investigation (Appendix 5), used to verify the effects of the intervention on the students' use of the different reading comprehension strategies.

- The comprehension questions following the assigned reading, Oliver Twist, (Appendix 6), including pre-reading, multiple-choice, matching, quotations, and open-ended questions, were used during the experiment.

- A strategy instruction guide, including the guides used and the procedures followed by the researcher during the intervention (Appendix 7).

To establish the content validity of the instruments, they were presented to a panel of jury members to evaluate them, and they agreed on their validity. The test/re-test was used to determine the reliability of the reading comprehension tests, and the correlation coefficient for the pre-test was 0.83 , and the post-test was 0.82 , which means that they are quite reliable.

\section{Procedures}

One week before starting the experiment, all students $(\mathrm{N}=63)$ completed the pre-questionnaire and the preliminary pilot reading comprehension test. Oxford graded reader test and the reading comprehension strategies questionnaire were administered as a pretest. The pre-questionnaire aimed to collect preliminary information about the students' experience with reading in English. Its results, in Table (1), manifest that many students suffered from problems in reading and comprehending English longer authentic texts and they have many difficulties in getting the main ideas and subordinate ones, extracting details and information, answering the questions after reading, and guessing the meaning of unknown words. 
Table 1. The participants' responses to the Pre-questionnaire

\begin{tabular}{|c|l|c|c|c|c|c|c|c|}
\hline \multirow{2}{*}{$\#$} & \multicolumn{1}{|c|}{ Questions } & \multicolumn{2}{|c|}{ Yes } & \multicolumn{2}{|c|}{ Sometimes } & \multicolumn{3}{|c|}{ No } \\
\cline { 3 - 10 } & & $\mathrm{N}$ & $\%$ & $\mathrm{~N}$ & $\%$ & $\mathrm{~N}$ & $\%$ \\
\hline \hline 1 & Do you like English language? & 32 & 51.61 & 21 & 33.87 & 10 & 16.13 \\
\hline 2 & Do you like reading in English? & 28 & 45.16 & 25 & 39.68 & 10 & 16.13 \\
\hline 3 & $\begin{array}{l}\text { Do you have trouble understanding what you } \\
\text { read in English? }\end{array}$ & 48 & 77.42 & 11 & 17.74 & 4 & 6.35 \\
\hline 4 & $\begin{array}{l}\text { Is it easy for you to get the main idea of what you } \\
\text { read? }\end{array}$ & 30 & 48.39 & 25 & 39.68 & 8 & 12.90 \\
\hline 5 & $\begin{array}{l}\text { Is it difficult for you to answer the questions after } \\
\text { reading? }\end{array}$ & 49 & 79.03 & 10 & 16.13 & 4 & 6.35 \\
\hline \multicolumn{2}{|c|}{ Does the teacher guide you on how to: } & & & & \\
\hline 6 & Get the main idea from the text. & 36 & 58.06 & 19 & 30.65 & 8 & 12.90 \\
\hline 7 & Get the important details in the text. & 34 & 54.84 & 21 & 33.87 & 8 & 12.90 \\
\hline 8 & Understand the meaning of unknown words. & 30 & 48.39 & 21 & 33.87 & 11 & 17.74 \\
\hline 9 & Use the dictionary or the glossary. & 26 & 41.27 & 13 & 20.63 & 24 & 38.09 \\
\hline 10 & Summarize what you read. & 22 & 35.48 & 16 & 25.39 & 25 & 40.32 \\
\hline
\end{tabular}

\section{Pre-testing results}

The scores of the preliminary pilot reading comprehension test were analyzed using the Independent-samples t-test, and there was no significant difference between the students, STDV $=0.393259$, which assured that the participants were homogeneous. To justify the other intended purpose of the test, which was to document the problem of the study, descriptive statistics were used, and the results showed that the mean score was 15.58 out of 30 , and the standard deviation was 4.89 , which proved the existence of the problem. Meanwhile, the results of the Oxford graded reader pretest showed no significant difference between the students $(\mathrm{STDV}=0.163)$. As for the reading strategies questionnaire, the students' responses indicated that some of them were using a few of the strategies subconsciously, without knowing it, while some others 
rarely used any of the strategies or even heard of them, relying on the teachers' help whose assistance most likely came in the form of giving the explanation and clarification of difficult pedagogical points in Arabic, the native language. The majority of the respondents agreed on the fact that the teachers' main concern, most of the time, was teaching grammar rules and new vocabulary, and their primary resort would be translated into Arabic.

\section{The experimental procedure}

The researcher prepared EGR materials, with enough copies for all the students to be used as a teaching resource. The idea was that every student in both the traditional and intervention group would have a copy of the same reading materials. She had to make appropriate arrangements to make the EGR part of the class time. How students read the text depended on many factors, including class time availability, students' motivation levels, and homeroom teacher's willingness to participate in the experiment. The researcher adjusted the strategies used to deal with such situations, between reading silently or aloud, individually or in pairs or small groups, paired reading, or taking the materials home to allow the students to read at their own pace, suiting their circumstances. However, the researcher was sensitive in valuing students' opinions to guarantee their consistent high motivation. The great merit about reading longer authentic texts together was to encourage students to see reading as a pleasurable part of EFL learning and not something to tolerate unwillingly.

All students, both classes, took part in an eight-week extensive graded reading program requiring them to read 30 minutes per week in class; using the selected materials the researcher prepared and at least 90 minutes of reading time per week outside of class; including the assigned graded reader "Oliver Twist"; which totaled 120 minutes = two hours per week. Since the participants' vocabulary was limited, the students were recommended to read only one chapter of the assigned book, Oliver Twist, per week. Each chapter had its comprehension questions, including pre-reading questions, multiple-choice questions, open-response, and essay questions, which were used to track the 
participants' reading proficiency development. The researcher tried to create a positive classroom environment, supported and encouraged the students' outside class reading by giving inspiring positive feedback, and answer any questions concerning what they read. As for outside-classreading, both classes were asked to keep reading diaries that were checked weekly. In the reading diaries, the participants listed the title of the chapter they were reading, the number of minutes they read per day, their answers for the comprehension questions, and their reaction of whether they were enjoying what they read.

The intervention group received reading strategy instruction for eight weeks. Strategy instruction was integrated into the materials selected by the researcher. The purpose was to help students become skilled, strategic readers who could comprehend what they were reading and enjoying it at the same time. The materials selected by the researcher contained four thematic units, with varied topics to appeal to the different tastes and interests of the students. The units contained excerpts from graded readers, which allow the researcher to use authentic extensive reading texts to teach and encourage students to engage in extensive graded reading. At the beginning of each unit, in the first session, the researcher focused on teaching and practicing reading and comprehension strategies, while in the second session, she focused on increasing the fluency of applying the learned strategies. The taught strategies were recycled throughout the sessions to ensure that students are not only introduced to them but also have enough opportunities to practice the learned strategies.

The intervention group was taught various comprehension strategies, including finding main ideas in the text, questioning, summarizing, and predicting, identifying meaning from context, using KWL, SMART, paired reading, and reinforcing reading with writing. The reading strategies comprised: skimming for main ideas, scanning for specific information, recognizing points of view, ignoring unimportant, unknown words, recognizing reference words and signal words, using the different reading guides; process, concept, content, text connection, interactive, guide-O-Rama, glossing and graphic organizers. 
The procedures for the used strategies and the steps the researcher followed were shown in Appendix 6. Throughout the eight weeks, the researcher also used the exercises sections that appeared throughout the selection with the intervention group for applying and practicing the learned strategies and training on the procedures for using them efficiently.

After teaching each reading strategy, the researcher asked the participants to read the task required in the text over silently, and then she gave a hint to the class relating the task to the strategy taught and called on a student to provide a concrete example of how she would put this strategy into action when solving the task at hand. The participants then practiced the strategies while they read and completed exercises in the selection, which reinforced the practice of the strategies. Afterward, the researcher selected a student to share with the class where specifically, within the text, she had applied the strategy. The researcher emphasized the fact that these strategies could and should be applied to their outside-class-reading, including not only their graded readers but any English text they read.

The regular group read the same materials as the intervention group. The material consisted of the same photocopied version of the selected materials, but without the strategy, instruction taught to the intervention group. Thus, the regular group was not given any strategy instruction. The researcher rather used the traditional method of reading instruction to teach the regular group, which emphasized intensive reading exercises, which included comprehension questions, grammar, language analysis, and other independent reading or comprehension work. The traditional method of instruction began by introducing new vocabulary by providing Arabic translation and example sentences. The students were asked, then, to read the text silently before the researcher's explanation of it, sentence by sentence in Arabic while highlighting grammar patterns in the text. Next, the students answered 
comprehension questions about the text, individually or as a class. When the wrong answers were given, the researcher pointed out the part in the text that provided the correct answers.

In the pedagogical application, during extensive graded reading, the students instinctively grasp new vocabulary and grammatical structures while reading and should be able to recycle the vocabulary and revisit the structures in their writing tasks. Consequently, the researcher tried to make use of reading as a means to enhance the students' writing ability instead of teaching writing skills separately. The various strategies taught to the intervention group combined the two skills to promote not only a skillful reader simultaneously but also foster a capable writer. The underlying practice was to use reading as a resource to elaborate on ideas to enhance their writing tasks, while at the same time using writing tasks as a learning tool in teaching reading strategies. So, all participants were asked to write an essay related to the topic after finishing each unit, and they were collected concurrently. Their essay writing abilities were evaluated every week throughout the entire eight weeks, but there was neither instruction nor practice in writing skills, for either group.

To sum up, the intervention group was provided extensive graded reading integrated with reading and comprehension strategy instruction for eight weeks while the regular group was taught using the traditional intensive reading instruction for the eight weeks. Both classes had the outside-class-reading, but the intervention group was guided through the reading process, directed to use the strategies taught, and received feedback to help them to read more fluently and comprehend what they read more easily and enjoy their reading. The regular group did not receive any guidance or recommendations with their outside-classreading from the researcher. After the eight-week intervention, both classes took the Oxford Graded Reader Test (Version 2) and completed the reading and comprehension strategies questionnaire as a post-test. 


\section{Results and discussion}

The results and discussion are presented in response to each of the study questions.

\section{Question 1}

To what extent does extensive graded reading affect secondary stage students' EFL reading proficiency?

Oxford Graded Reader Test (Version 1) was administered on all the students, and the analysis of scores showed that STDV $=0.163$. Table (2) shows the descriptive statistical results.

Table 2. The participants' scores in the pre-test/ Oxford Reader Test/Level 6 (version 1)

\begin{tabular}{|c|c|c|c|c|c|c|c|c|}
\hline & $\mathrm{N}$ & Mean & $\begin{array}{c}\text { Std. } \\
\text { Deviation }\end{array}$ & $\begin{array}{c}\text { Std. Error } \\
\text { Mean }\end{array}$ & $\mathrm{t}$ & $\mathrm{df}$ & $\begin{array}{c}\text { Sig. (2- } \\
\text { tailed) }\end{array}$ & $\begin{array}{c}\text { Mean } \\
\text { Diff. }\end{array}$ \\
\hline $\begin{array}{c}\text { Mean. } \\
\text { Pre }\end{array}$ & 63 & .5196 & .16326 & .02057 & 25.26 & 62 & .000 & .5195 \\
\hline
\end{tabular}

Comparing the score of the participants, the traditional group and the intervention one, indicated that their reading proficiency was very close to each other, shown in Table (3).

Table 3. The comparison between the two groups' scores in the pre-test

\begin{tabular}{|c|c|c|c|}
\hline Group & $\mathbf{N}$ & Mean & Std. Deviation \\
\hline Trad. Group & 31 & .5247 & .18073 \\
\hline Interv. Group & 32 & .5146 & .14712 \\
\hline
\end{tabular}

When running the independent samples t-test on the intervention and traditional groups' pre-test scores, the results did not reveal any statistically significant difference $(\mathbf{t}=0.245, \mathbf{p}=0.807$, Cohen's $\mathbf{d}=\mathbf{0 . 6 2}$ ), as shown in Table (4). 
Table 4. The difference between the traditional group and the intervention one in the pre-test score

\begin{tabular}{|c|c|c|c|c|c|c|c|c|c|}
\hline & \multirow[t]{2}{*}{$\mathbf{F}$} & \multirow[t]{2}{*}{ Sig } & \multirow[t]{2}{*}{$\mathbf{t}$} & \multirow[t]{2}{*}{ df } & \multirow{2}{*}{$\begin{array}{l}\text { Sig. } \\
2- \\
\text { tailed }\end{array}$} & \multirow{2}{*}{$\begin{array}{c}\text { Mean } \\
\text { Diff. } \\
\text { Cohen's d }\end{array}$} & \multirow{2}{*}{$\begin{array}{l}\text { Std. Error } \\
\text { Difference }\end{array}$} & \multicolumn{2}{|c|}{$\begin{array}{l}\text { 95\% Confidence } \\
\text { Interval of the } \\
\text { Difference }\end{array}$} \\
\hline & & & & & & & & Lower & Upper \\
\hline Mean & 1.41 & .24 & .245 & 61 & .807 & .01015 & .04146 & -.0727 & .0930 \\
\hline Zscore & 1.41 & .24 & .245 & 61 & .807 & .062157 & .253940 & -.4456 & .5699 \\
\hline
\end{tabular}

However, a statistically highly significant difference was shown in Table (5) between the two groups in the post-test scores. The finding of this study indicated consistency with previous studies, which found that EFL students who had extensive graded reading outperformed those students who took part in intensive graded reading (Burrows, 2012).

Table 5. The comparison between the traditional group and the intervention one' scores in the post-test using the Oxford Graded Reader/Level 6 (Version2)

\begin{tabular}{|l|c|c|c|c|c|}
\hline & Group & $\mathrm{N}$ & Mean & Std. Deviation & Std. Error Mean \\
\hline \multirow{3}{*}{ Mean. Post } & Trad. Group & 31 & .2984 & .17724 & .03183 \\
\cline { 2 - 6 } & Interv. Group & 32 & .7625 & .21402 & .03783 \\
\hline
\end{tabular}

After running the independent samples t-test on both intervention and traditional groups' post-test scores, the results revealed statistically significant differences in their post-test scores $(\mathbf{t}=-9.36, \mathbf{p}=0.000$, Cohen's $\mathbf{d}=-1.523$ ), as shown in Table (6). 
Table (6). The comparison between the two groups' scores in the post-test

\begin{tabular}{|c|c|c|c|c|c|c|c|c|c|}
\hline & & \multirow[t]{2}{*}{ g. } & & \multirow[t]{2}{*}{ df } & \multirow{2}{*}{$\begin{array}{l}\text { Sig. } \\
\text { (2- } \\
\text { tailed) }\end{array}$} & \multirow{2}{*}{$\begin{array}{l}\text { Mean } \\
\text { Difference } \\
\text { Cohen's } \\
\text { d) }\end{array}$} & \multirow{2}{*}{$\begin{array}{c}\text { Std. } \\
\text { Error } \\
\text { Difference }\end{array}$} & \multicolumn{2}{|c|}{$\begin{array}{l}95 \% \text { Confidence } \\
\text { Interval of the } \\
\text { Difference }\end{array}$} \\
\hline & & & & & & & & Lower & Upper \\
\hline ore & 1.697 & .198 & -9.358 & 61 & .000 & -1.5234 & 1627 & -1.8489 & -1.1979 \\
\hline
\end{tabular}

This kind of result would be inspiring to EFL teachers, who could utilize reading strategy instruction for improving their students' reading proficiency. As evidenced by the results, in only eight weeks of reading strategy instruction, EFL students did make significant developments in their EFL reading proficiency and comprehension.

\section{Question 2}

To what degree does reading strategy instruction affect secondary stage students' EFL comprehension skills?

In the current study, the researcher administered the reading strategies questionnaire to obtain the participants' perceptions of reading strategies, and their choice reflected self-reported strategy use during the reading process. The first administration of the questionnaire, the pre-test, took place before any intervention or training on using the different reading comprehension strategies. All participants, both the traditional and the intervention groups, responded to the reading strategies questionnaire. The results of the pre-test of the questionnaire, shown in Table (7), indicated that some of the respondents were not familiar with many of the reading strategies, and tended to have a neutral response in most cases. The neutral responses were more than $15 \%$ for statements $2 \& 3$, more than $20 \%$ for statements $7,8,10,11,14 \& 16$, and more than $30 \%$ for statements $5,6,12,15$, $17,18,19,20$. Meanwhile, the statements that had negative connotations, $1,4,9,13$, and 16 were mostly answered positively, with the consecutive percentages $78 \%, 70 \%, 85 \%, 65 \%$, and $68 \%$, which meant that most of the respondents were using these types of unwanted strategies when reading. Very few of the respondents made the right choice when they read and selected suitable reading strategies to apply. 
Table 7. Numbers and percentages of the participants' responses to the Reading Strategies questionnaire

\begin{tabular}{|c|c|c|c|c|c|c|}
\hline \# & Statement & SD & D & $\mathbf{N}$ & $\mathbf{A}$ & SA \\
\hline \multirow{2}{*}{1} & \multirow{2}{*}{$\begin{array}{l}\text { *Focus on understanding the grammatical } \\
\text { structures in the text }\end{array}$} & 2 & 3 & 9 & 13 & 36 \\
\hline & & $3 \%$ & $5 \%$ & $14 \%$ & $21 \%$ & $57 \%$ \\
\hline \multirow[b]{2}{*}{2} & \multirow{2}{*}{$\begin{array}{l}\text { Use a variety of context clues to understand the } \\
\text { parts I do not understand in the text }\end{array}$} & 27 & 20 & 10 & 5 & 1 \\
\hline & & $43 \%$ & $32 \%$ & $16 \%$ & $8 \%$ & $1 \%$ \\
\hline \multirow{2}{*}{3} & \multirow{2}{*}{$\begin{array}{l}\text { Read the first line of each paragraph to get the } \\
\text { meaning of the text }\end{array}$} & 18 & 20 & 12 & 8 & 5 \\
\hline & & $28 \%$ & $32 \%$ & $19 \%$ & $13 \%$ & $8 \%$ \\
\hline \multirow[b]{2}{*}{4} & \multirow{2}{*}{$\begin{array}{l}\text { * Read each word in the text and look up unknown } \\
\text { words in the dictionary }\end{array}$} & 5 & 7 & 7 & 26 & 18 \\
\hline & & $8 \%$ & $11 \%$ & $11 \%$ & $41 \%$ & $29 \%$ \\
\hline \multirow{2}{*}{5} & \multirow{2}{*}{$\begin{array}{l}\text { Use my background knowledge and prior } \\
\text { experiences to understand the text }\end{array}$} & 8 & 17 & 21 & 10 & 7 \\
\hline & & $13 \%$ & $27 \%$ & $33 \%$ & $16 \%$ & $11 \%$ \\
\hline \multirow{2}{*}{6} & \multirow{2}{*}{$\begin{array}{l}\text { Expect certain things from following the } \\
\text { organization of the whole text }\end{array}$} & 5 & 9 & 29 & 12 & 8 \\
\hline & & $8 \%$ & $14 \%$ & $46 \%$ & $19 \%$ & $13 \%$ \\
\hline \multirow[b]{2}{*}{7} & \multirow{2}{*}{$\begin{array}{l}\text { Look through the text quickly to make sure that I } \\
\text { know most of the words }\end{array}$} & 7 & 22 & 18 & 10 & 6 \\
\hline & & $11 \%$ & $35 \%$ & $29 \%$ & $16 \%$ & $9 \%$ \\
\hline \multirow{2}{*}{8} & \multirow[t]{2}{*}{ Understand all the details in the text } & 12 & 30 & 16 & 4 & 1 \\
\hline & & $19 \%$ & $48 \%$ & $25 \%$ & $6 \%$ & $2 \%$ \\
\hline \multirow[b]{2}{*}{9} & \multirow{2}{*}{$\begin{array}{l}\text { *Underline the unknown words, phrases, } \\
\text { sentences I do not understand and translate them } \\
\text { into Arabic as much as I can }\end{array}$} & 0 & 1 & 8 & 32 & 22 \\
\hline & & $0 \%$ & $2 \%$ & $13 \%$ & $50 \%$ & $35 \%$ \\
\hline \multirow{2}{*}{10} & \multirow{2}{*}{$\begin{array}{l}\text { Study the topic sentence and figure out the content } \\
\text { of the text }\end{array}$} & 6 & 17 & 17 & 12 & 11 \\
\hline & & $10 \%$ & $27 \%$ & $27 \%$ & 19 & $17 \%$ \\
\hline \multirow{2}{*}{11} & \multirow{2}{*}{$\begin{array}{l}\text { Pay attention to the parts of the word to guess the } \\
\text { meaning of unknown words in the text }\end{array}$} & 10 & 21 & 18 & 11 & 3 \\
\hline & & $16 \%$ & $33 \%$ & $29 \%$ & $17 \%$ & $5 \%$ \\
\hline \multirow{2}{*}{12} & \multirow{2}{*}{$\begin{array}{l}\text { Recognize the difference between the main idea } \\
\text { and supporting details in the text }\end{array}$} & 8 & 17 & 23 & 13 & 2 \\
\hline & & $13 \%$ & $27 \%$ & $36 \%$ & $21 \%$ & $3 \%$ \\
\hline \multirow{2}{*}{13} & *Understand the meaning of each word in the text & 5 & 13 & 4 & 23 & 18 \\
\hline & & $8 \%$ & $21 \%$ & $6 \%$ & $36 \%$ & $29 \%$ \\
\hline & Reread the parts of the text I do not understand & 4 & 19 & 18 & 17 & 5 \\
\hline 14 & $\begin{array}{l}\text { ask myself related } \\
\text { me guesses }\end{array}$ & $6 \%$ & $30 \%$ & $29 \%$ & $27 \%$ & $8 \%$ \\
\hline 15 & parts of the text to & 9 & 12 & 22 & 13 & 7 \\
\hline & each & $14 \%$ & $19 \%$ & $35 \%$ & $21 \%$ & $11 \%$ \\
\hline 16 & ind carefully so that I will not miss & 4 & 3 & 13 & 10 & 33 \\
\hline 10 & any $\mathrm{p}$ & $6 \%$ & $5 \%$ & $21 \%$ & $16 \%$ & $52 \%$ \\
\hline & Skim the whole text first to get the general idea & 8 & 18 & 20 & 13 & 4 \\
\hline 17 & & $13 \%$ & $28 \%$ & $32 \%$ & $21 \%$ & $6 \%$ \\
\hline 18 & sented in the text & 7 & 15 & 24 & 12 & 5 \\
\hline 1 & & $11 \%$ & $24 \%$ & $38 \%$ & $19 \%$ & $8 \%$ \\
\hline 19 & Pay attention to punctuation and transition wor & 12 & 13 & 28 & 6 & 4 \\
\hline 19 & in the & $19 \%$ & $21 \%$ & $44 \%$ & $10 \%$ & $6 \%$ \\
\hline 20 & Skip the parts I do not understand and keep & 11 & 20 & 23 & 7 & 2 \\
\hline 20 & readil & $17 \%$ & $32 \%$ & $37 \%$ & $11 \%$ & $3 \%$ \\
\hline
\end{tabular}

* Reversed scoring/ statements with negative connotations 
A One-Sample t-test was used to examine the participants' knowledge and use of the different reading strategies, getting the statistical analysis of the participants' scores in the pre-test and post-test administration of the reading strategies questionnaire. The results are shown in Table (8).

Table 8. The participants' scores in the pre-test and post-test of the reading strategies questionnaire

\begin{tabular}{||c|c|c|c|c|c|c|}
\hline & Group & $\mathbf{N}$ & Mean & $\begin{array}{c}\text { Std. } \\
\text { Deviation }\end{array}$ & $\begin{array}{c}\text { Std. Error } \\
\text { Mean }\end{array}$ & $\mathbf{t}$ \\
\hline \hline \multirow{3}{*}{ Mean (Pre) } & Trad. Group & 31 & 2.5516 & .66951 & .12025 & 21.22 \\
\cline { 2 - 7 } & Interv. Group & 32 & 2.5313 & .54960 & .09716 & 26.05 \\
\hline \multirow{2}{*}{ Mean (Pre) } & Total & 63 & 2.5413 & .6067 & .07643 & 33.25 \\
\cline { 2 - 7 } & Trad. Group & 31 & 2.5919 & .62983 & .11312 & 22.91 \\
\hline \multirow{2}{*}{ Mean. (Post) } & Interv. Group & 32 & 3.6812 & .33354 & .05896 & 62.43 \\
\cline { 2 - 7 } & Total (Post) & 63 & 3.1452 & .74090 & .09334 & 33.70 \\
\hline
\end{tabular}

Table (8) indicates that there were no statistically significant differences in the two groups in the pre-test, but the results of the posttest show that there were significant differences in the postadministration.

Independent samples t-test was used, comparing the traditional and intervention groups' pre-test and post-test administration scores, to inspect whether reading strategy instruction influenced participants' reading strategies use,

Table 9. The comparison between the traditional group and the intervention group in the pre-test and post-test administration scores of the reading strategies questionnaire

\begin{tabular}{||c|c|c|c|c|c|c|c|c|c|c||}
\hline & $\mathbf{F}$ & Sig. & $\mathbf{t}$ & $\mathbf{d f}$ & $\begin{array}{c}\text { Sig. (2- } \\
\text { tailed) }\end{array}$ & $\begin{array}{c}\text { Mean } \\
\text { Diff. }\end{array}$ & $\begin{array}{c}\text { Mean Diff. } \\
\text { (Cohen's d) }\end{array}$ & $\begin{array}{c}\text { Std. } \\
\text { Error } \\
\text { Diff. }\end{array}$ & Lower & Upper \\
\hline \hline $\begin{array}{c}\text { Mean } \\
\text { (Pre) }\end{array}$ & 1.697 & .198 & .132 & 61 & .895 & .02036 & .0336 & .1541 & -.2877 & .3285 \\
\hline $\begin{array}{c}\text { Mean. } \\
\text { Post }\end{array}$ & 16.14 & .000 & -8.617 & 61 & .000 & -1.089 & -1.4702 & .1264 & -1.342 & -.8365 \\
\hline
\end{tabular}


As shown in Table (9), there was no statistically significant difference between the traditional group and the intervention one; $\mathrm{t}=$ $0.132, p=0.895$, Cohen's $d=0.034$, in the use of reading strategies. Meanwhile, the post-test administration pointed out that there were statistically significant differences between the scores of the two groups after the intervention; $\mathrm{t}=-8.62, \mathrm{p}=0.000$, Cohen's $\mathrm{d}=-1.09$, in favor of the intervention group.

Participants' use was also checked using paired samples t-test to compare between the pretest and posttest scores for both groups. Table (10) details the results.

\section{Table 10. The detailed comparison between the traditional group and} the intervention group in the reading strategies questionnaire's scores

\begin{tabular}{|c|c|c|c|c|c|c|c|c|c|}
\hline & & & & & \multicolumn{2}{|c|}{$\begin{array}{l}\text { 95\% Confidence } \\
\text { Interval of the } \\
\text { Difference } \\
\end{array}$} & & & \\
\hline & & & & & Lower & Upper & & & \\
\hline Pair 1 & $\begin{array}{l}\text { Trad. Pre/ } \\
\text { Interv. Pre }\end{array}$ & Mean & Std. D & $\begin{array}{l}\text { Std. } \\
\text { Error } \\
\text { Mean } \\
\end{array}$ & -.2988 & .3214 & $\mathrm{t}$ & $\mathrm{df}$ & $\begin{array}{l}\text { Sig.(2- } \\
\text { tailed) }\end{array}$ \\
\hline Pair 2 & $\begin{array}{c}\text { Trad. } \\
\text { Post/ Interv. } \\
\text { Post } \\
\end{array}$ & & & & -1.3591 & -.8311 & & & \\
\hline Pair 3 & $\begin{array}{l}\text { Trad. Pre/ } \\
\text { Trad. Post }\end{array}$ & .0113 & .8454 & .1518 & -.0833 & .0027 & & & \\
\hline Pair 4 & $\begin{array}{l}\text { Interv. Pre/ } \\
\text { Interv. Post }\end{array}$ & -1.095 & .7199 & .1293 & -1.2575 & -1.0425 & .074 & 30 & .941 \\
\hline & & -.0403 & .1172 & .0211 & & & -8.47 & 30 & .000 \\
\hline & & -1.150 & .2981 & .0527 & & & -1.92 & 30 & .065 \\
\hline & & & & & & & -21.82 & 31 & .000 \\
\hline
\end{tabular}

Results showed a statistically significant difference between the pre-test and post-test scores of the reading strategies questionnaire for the intervention group; $\mathbf{t}=-21.82, \mathbf{p}=.000$, but not for the traditional group $\mathbf{t}=-1.92, \mathbf{p}=.065$. The result further indicated there was a difference between the two groups in the post-administration scores; $t=-0.83, \mathrm{p}$ 
$=0.000$, which proved that the intervention group's use of strategies increased, while the traditional group showed slight or no improvement.

\section{Question 3}

What is the effect of integrating extensive graded reading with reading strategy instruction on secondary stage students' EFL comprehension skills?

Table 11. The comparison between the traditional and intervention groups' scores in the pre-test and their scores in the post-test

\begin{tabular}{|c|c|c|c|c|c|c|c|c|c|c|c|}
\hline & Group & $\mathrm{N}$ & $\begin{array}{c}\text { Mea } \\
n\end{array}$ & $\begin{array}{c}\text { Std. } \\
\text { D }\end{array}$ & $\begin{array}{l}\text { Std. } \\
\text { Err }\end{array}$ & $\mathrm{F}$ & Sig. & $\mathrm{t}$ & df & $\begin{array}{l}\text { Sig. } \\
(2- \\
\text { tailed })\end{array}$ & $\begin{array}{l}\text { Mean } \\
\text { Diff. }\end{array}$ \\
\hline \multirow{2}{*}{$\begin{array}{l}\text { Mean. } \\
\text { Pre }\end{array}$} & $\begin{array}{l}\text { Trad. } \\
\text { Group }\end{array}$ & 31 & .531 & . 188 & .034 & \multirow[b]{2}{*}{.032} & \multirow[b]{2}{*}{.860} & \multirow[b]{2}{*}{.397} & \multirow[b]{2}{*}{61} & \multirow[b]{2}{*}{.693 } & \multirow[b]{2}{*}{.0187. } \\
\hline & $\begin{array}{l}\text { Interv. } \\
\text { Group }\end{array}$ & 32 & .512 & .185 & .033 & & & & & & \\
\hline \multirow{2}{*}{$\begin{array}{l}\text { Mean. } \\
\text { Post }\end{array}$} & $\begin{array}{l}\text { Trad. } \\
\text { Group }\end{array}$ & 31 & .298 & 177 & . 0318. & \multirow[b]{2}{*}{1.69} & \multirow[b]{2}{*}{. 198} & \multirow[b]{2}{*}{-9.35} & \multirow[b]{2}{*}{61} & \multirow[b]{2}{*}{.000} & \multirow[b]{2}{*}{-.464} \\
\hline & $\begin{array}{l}\text { Interv. } \\
\text { Group }\end{array}$ & 32 & .763 & .214 & .0378 & & & & & & \\
\hline
\end{tabular}

In the pre-test administration of the reading strategy questionnaire, the mean scores of items ranged from 1.70 to 3.50 , whereas in the posttest one, after the intervention, they fluctuated from 2.50 to 4.0 . The total mean in the pre-administration was 2.53 , and it went up in the postadministration to be 3.11, as shown in Table (12).

Table 12. One sample t-test results of the intervention group scores in the pre- and post administration of the reading strategies questionnaire

\begin{tabular}{|c|c|c|c|c|c|c|c|c|c|}
\hline & $\mathrm{N}$ & Mean & Std. D & Std. Err. & $\mathrm{t}$ & $\mathrm{df}$ & Sig. (2-tailed) & Lower & Upper \\
\hline \hline $\begin{array}{c}\text { RS.Pre } \\
32\end{array}$ & 2.531 & .5496 & .09716 & 26.053 & 31 & .000 & 2.3331 & 2.7294 \\
\hline RS.Post & 32 & 3.117 & .4614 & .08156 & 38.222 & 31 & .000 & 2.9509 & 3.2835 \\
\hline
\end{tabular}

The results are showing higher means, which can be a reflection of the elevated use of reading strategies after the intervention. The reading 
strategies questionnaire collected data was further analyzed deeper to compare the type of reading strategies used by the intervention group before and after the intervention; the strategies used before and after the intervention were the same, but their use " percentage and ranking was different, as shown in Table (13).

\section{Table 13. Comparison between the reading strategies used before and after the intervention}

\begin{tabular}{|c|c|c|c|c|c|}
\hline \# & Statement & $\begin{array}{c}\% \\
\text { Pre }\end{array}$ & $\begin{array}{c}\text { Rank } \\
\text { Pre }\end{array}$ & $\begin{array}{c}\% \\
\text { Post }\end{array}$ & $\begin{array}{c}\text { Rank } \\
\text { Post }\end{array}$ \\
\hline 1 & $\begin{array}{l}\text { *Focus on understanding the grammatical structures in the } \\
\text { text }\end{array}$ & $78 \%$ & 2 & $35 \%$ & 14 \\
\hline 2 & $\begin{array}{l}\text { Use a variety of context clues to understand the parts I do not } \\
\text { understand in the text }\end{array}$ & $9 \%$ & 16 & $51 \%$ & 6 \\
\hline 3 & $\begin{array}{l}\text { Read the first line of each paragraph to get the meaning of } \\
\text { the text }\end{array}$ & $21 \%$ & 13 & $68 \%$ & 2 \\
\hline 4 & $\begin{array}{l}\text { *Read each word in the text and look up unknown words in } \\
\text { the dictionary }\end{array}$ & $70 \%$ & 3 & $43 \%$ & 10 \\
\hline 5 & $\begin{array}{l}\text { Use my background knowledge and prior experiences to } \\
\text { understand the text }\end{array}$ & $27 \%$ & 9 & $58 \%$ & 4 \\
\hline 6 & $\begin{array}{l}\text { Expect certain things from following the organization of the } \\
\text { whole text }\end{array}$ & $32 \%$ & 8 & $45 \%$ & 9 \\
\hline 7 & $\begin{array}{l}\text { Look through the text quickly to make sure that I know most } \\
\text { of the words }\end{array}$ & $25 \%$ & 10 & $63 \%$ & 3 \\
\hline 8 & Understand all the details in the text & $8 \%$ & 17 & $41 \%$ & 11 \\
\hline 9 & $\begin{array}{l}\text { *Underline the unknown words, phrases, sentences I do not } \\
\text { understand and translate them into Arabic as much as I can }\end{array}$ & $85 \%$ & 1 & $48 \%$ & 8 \\
\hline 10 & Study the topic sentence and figure out the content of the text & $36 \%$ & 6 & $68 \%$ & 2 \\
\hline 11 & $\begin{array}{l}\text { Pay attention to the parts of the word to guess the meaning of } \\
\text { unknown words in the text }\end{array}$ & $22 \%$ & 12 & $48 \%$ & 8 \\
\hline 12 & $\begin{array}{l}\text { Recognize the difference between the main idea and } \\
\text { supporting details in the text }\end{array}$ & $24 \%$ & 11 & $53 \%$ & 5 \\
\hline 13 & *Understand the meaning of each word in the text & $65 \%$ & 5 & $38 \%$ & 12 \\
\hline 14 & $\begin{array}{l}\text { Reread the parts of the text I do not understand several more } \\
\text { times and ask myself related questions, then try to make } \\
\text { some guesses }\end{array}$ & $35 \%$ & 7 & $51 \%$ & 6 \\
\hline 15 & Relate information in different parts of the text to each other & $32 \%$ & 8 & $45 \%$ & 9 \\
\hline 16 & $\begin{array}{l}\text { *Read slowly and carefully so that I will not miss any parts } \\
\text { of the text }\end{array}$ & $68 \%$ & 4 & $37 \%$ & 13 \\
\hline 17 & Skim the whole text first to get the general idea & $27 \%$ & 9 & $73 \%$ & 1 \\
\hline 18 & Question the viewpoints presented in the text & $27 \%$ & 9 & $43 \%$ & 10 \\
\hline 19 & Pay attention to punctuation and transition words in the text & $16 \%$ & 14 & $50 \%$ & 7 \\
\hline 20 & $\begin{array}{l}\text { Skip the parts I do not understand and keep reading to get the } \\
\text { overall meaning of the text }\end{array}$ & $14 \%$ & 15 & $48 \%$ & 8 \\
\hline
\end{tabular}


Many findings were worth noting; the use of Arabic translation, statement 9, was noticeably decreased; this could be due to the strategy instruction that offered them some effective alternatives for translation to understand the meaning of the unknown vocabulary, such as the ones in statements 2; using context clues, and 11; knowing the meaning from word parts. The focus on understanding the grammatical structures deteriorated in the ranking. The reading strategies that were emphasizing comprehending the gist of the text, such as statements 10; the topic sentence, 17, skimming, and 20; getting the overall meaning, received rather higher ranking after the intervention. The participants realized that they could continue reading and use the surrounding context and clues to guess the meanings of unknown vocabulary. They might have decided to go, partially, for comprehending the whole text instead of their previous complete reliance on bottom-up reading strategies, which might be a sign of their reading proficiency improvement and comprehension skills development.

There was an apparent rise in using and ranking the strategy of using background knowledge, in statement 5 , this could be explained by the fact that the teacher/researcher was providing time for pre-reading exercises, focusing on activating the students' background knowledge about the topic, through discussion and brainstorming. The participants in the intervention group were led to think about the topic before reading the text. They were motivated to access their prior experiences and background information about each topic, which facilitated the texts' comprehension. This strategy might have become more pivotal for the improvement of the participants' comprehension skills because of its contrast with the traditional approach of intensive reading instruction, which never provided them with enough opportunities to think about what they were about to read. This finding called attention to the benefits of pre-reading activities, as a proficient reading strategy that EFL teachers and learners could adopt to improve their comprehension skills. Anderson (2007), Barrot (2016), and Wolf (2018) asserted that prior knowledge of the topic could be the best predictor of comprehension, and its activation could have special importance in 
generating predictions of the texts' content and promoting EFL readers' comprehension skills.

The use of context clues, statement 2 , had received a noticeable jump in ranking and the participants made use of this reading strategy, which included several sub-strategies; reading and analyzing title, text structure, noticing signal words, keywords, grammatical patterns, points of view and claims, and ending with conclusions. Previous research findings (Chen, 2005; Burrows, 2012; Shih\& Reynolds, 2015 and Barrot, 2016) had shown that EFL learners who had comprehension problems tended to use fewer reading strategies, and even when using them, it was rather casual. Therefore, the participants' use of this strategy more frequently after the intervention could be indicative of their application of a variety of reading strategies, which could consequently assist them to be more analytical, active, and proficient readers.

The ranking of some strategies did not change that much due to the limited time of intervention. Only eight weeks were not enough for the participants to familiarize themselves with all the strategies. Another interesting finding was the low ranking of statement 18, but it appeared that Egyptian students tend to accept the viewpoints in the text without arguing, because of the traditional educational system they went through, which might cause them a lot of problems when pursuing their higher education (Reynolds, 2013; Reynolds \& Anderson, 2015). The new educational pedagogies should emphasize critical thinking skills that could be developed through extensive graded reading integrated with comprehension strategies, which might consequently improve EFL learners' comprehension skills, and enable them to be proficient readers, and lead them, eventually, to be autonomous learners.

\section{Pedagogical implications and conclusions}

The current investigation aimed to explore the effects of integrating extensive graded reading with reading strategy instruction. The study's results indicated that extensive graded reading incorporated with reading strategy instruction had a positive effect on the intervention group's reading proficiency, strategies use, and comprehension skills. 
The participants in the intervention group appeared to have less use of bottom-up reading strategies while increasing their use of many of the taught strategies; background knowledge, use of context clues, and structural clues.

Even though the current study has revealed some interesting findings, it had several limitations. First, the original plan for the study, intended by the researcher, was to use mixed-methods investigation by online reading, collecting data from participants using eye-tracking and other online techniques, relying on the electronic educational devices, that the students were supposed to have. However, the delay in delivery and the accompanying technical problems hindered the original plan, and the researcher switched to plan $\mathrm{B}$, using the convenient offline, hard copies instruments. Collecting written data from the participants to analyze the effect of extensive graded reading with reading comprehension strategies on their writing skills was also part of the plan to triangulate the data, but it did not end up as planned, and the collected data was not enough to generalize the results. Second, the amount of extensive graded reading that took place inside the two classrooms during the eight weeks was limited to 30 minutes 3 days a week, and sometimes it ended up with only two times per week, following the rules set by the educational institution in which the research was conducted. Future researchers may determine to increase the amount of in-class extensive reading or rely more on the voluntary outside-class extensive reading students, facilitating a more autonomous learning and teaching environment, to engage the students.

Next, further analysis of the reading strategies questionnaire data resulted in acknowledging that the intervention group's use of taught strategies did increase more. However, these increases had to be cautiously interpreted, as the increase in reading strategies use combined with extensive graded reading was what helped to push the intervention group's reading comprehension scores up, but further randomized, longitudinal, experimental research with a control group and multiple experimental groups could make more concrete claims. In the end, no single instructional approach was likely to meet all the needs of EFL 
learners; any instructional technique might need to be adapted or combined to cater to students' individual diverse needs (Shih \& Reynolds, 2015). Lastly, the participants read texts from a selection that was combined mostly of excerpts taken from graded readers, in addition to the retold story of Oliver Twist. Barrot (2016) claimed that the types of strategies that EFL learners applied while reading was dependent upon the type of text being read. Future studies should try more than one reading genre to reach further significant results. Future researchers should also aim to determine whether the use of intensive reading strategies, extensive reading strategies, or both could be used to improve reading proficiency.

The instruction that the intervention group' participants received in the current investigation deviated from the traditional Egyptian style of teaching EFL reading in that it developed participants' knowledge about the reading process through introducing and demonstrating a set of reading comprehension strategies. Additionally, the participants were furnished with enough opportunities to practice the taught strategies while reading in and outside of class through extensive graded reading. Such instruction was a better alternative to traditional EFL reading instruction because it boosted students' reading proficiency and comprehension skills. Since the Egyptian students lack adequate training in reading strategies, the students in the traditional group were inclined to read texts word by word, thus struggling with reading comprehension. They tended to avoid lengthy reading texts that had unknown vocabulary words. Prospective teachers should be trained to emphasize and apply reading strategies while reading, which might assist students in achieving higher reading proficiency. This objective was not only achievable but also necessary to foster successful reading and writing habits in the students. Teachers had to encourage students to become independent readers and, eventually, autonomous learners. Students should try to use the structural and contextual clues to infer unknown word meanings, and not to reverse Arabic translation all the time. For large classroom sizes, the teacher could pair less proficient and proficient students together for in-class reading strategy practice. EFL teachers might be strongly encouraged to devote a portion of their class time to 
allow students to discuss and activate background knowledge on topics before reading, which could positively affect comprehension skills (Shih\& Reynolds, 2015).

One fundamental way to motivate learners to read more, as the research suggested, was to ensure the learners' choice of reading materials (Reynolds \& Bai, 2013). Another motivating way of encouraging the students was through having them read aloud. While reading aloud was frowned upon, especially at higher grades, it could be a helpful tool if used purposefully (Ntim, 2015; Kao, 2017). Future teachers of EFL should be encouraged to incorporate extensive reading into their classroom regimes. Several useful pieces of advice to teachers, who wish to incorporate extensive reading into their curriculum, could be offered including; ensuring the reading materials to be easy, a variety of topics in the reading materials to be available, learners to choose what they want to read, learners to read as much as possible, and the teacher to be a role model. As with the current investigation, the researcher ensured that the reading material was easy, using EFL vocabulary tests to assess the participants' vocabulary sizes and then matching them to graded readers with 98\% known vocabulary coverage (Nation \& Beglar, 2007; $\mathrm{Hu} \&$ Nation, 2000). Matching students' vocabulary sizes to appropriate graded readers ensured that students' comprehension would not be hindered while reading, with opportunities to encounter and acquire new vocabulary incidentally and recycle and retain previously known words (Reynolds, 2015).

The teacher must pay careful attention to the students' motivation in incorporating extensive reading into their EFL instruction, guide them through the process and explain why they should select texts that were easy and enjoyable to read, compared to the traditional approach where they may have always been given difficult texts to read. As with the current investigation, the participants were always excited when it was time for their meetings with the researcher, some of them would ask when the next session would be, to be sure not to be absent from school that day. Teachers might stretch class time to devote only a portion of it (around 30 minutes) once a week to extensive graded reading. During 
the allotted time, the teacher should act as a role model and read with students. Teachers could, as with the current investigation, ask students to keep a reading diary or discuss their reading within reading circles (Furr, 2011). The researcher asked the students to keep a reading diary and discuss their reading within reading circles and create graphic organizers for their readings instead of book reports.

The findings of this investigation have shed some light on EFL reading instruction in Egypt and offer EFL teachers an alternative instructional design, namely, extensive graded reading integrated with reading strategy instruction. It provided some helpful guidelines for EFL teachers that hopefully would inspire them to try more effective reading instruction, consequently, to increase the likelihood of improving their students' reading proficiency and boost their comprehension skills. Probably, this study could act as momentum to other educators, showing that alternative methods could be employed successfully in the EFL classroom to the benefit of not only the students but also the teachers' professional development. 


\section{References}

Ahmed, S. (2019). Digital posters to engage EFL students and develop their reading comprehension. Journal of Education and Learning, 8 (4), 169- 184.

Akhavan, N. (2017). Nonfiction Now Lesson Bank, Grades 4-8: Strategies and Routines for Higher-Level Comprehension in the Content Areas. Corwin Press: Sage Company.

Al-Nujaidi, A. H. (2003). The relationship between vocabulary size, reading strategies, and reading comprehension of EFL learners in Saudi Arabia. Unpublished Ph.D. dissertation. Oklahoma State University: Stillwater, Oklahoma.

Anderson, N. J. (2007). Active skills for reading: Book 2. Boston, MA: Thomson ELT.

Badawi, M. (2019). The effect of explicit English morphology instruction on EFL secondary school students' morphological awareness and reading comprehension. English Language Teaching, 12 (4), 166-178.

Bamford, J \& Day, R. (2004). Extensive reading activities for teaching language. Cambridge: Cambridge University Press.

Barrot, J. S. (2016). ESL learners' use of reading strategies across different text types. Asia-Pacific Education Researcher, 25(5-6), 883-892.

Burrows, L. (2012). The effects of extensive reading and reading strategies on reading self-efficacy. Unpublished Ph.D. dissertation. Temple University: Osaka, Japan.

Burt, M., Peyton, K., \& Adams, R. (2003). Reading and Adult English Language Learners: A Review of the Research. Washington, DC: Center for Applied Linguistics.

Chen, J. (2005). Explicit instruction of reading strategies at senior high school in Taiwan. Unpublished Master thesis. NKN University: Kaohsiung, Taiwan.

Cheng, C. (2003). Extensive reading, word-guessing strategies, and incidental vocabulary acquisition. In S. Huang \& C. Chern (Eds.), The Proceedings of the Twelfth International Symposium on English Teaching, pp. 188- 198. Taipei: The Crane

Day, R. (2011). Extensive reading: The background. In R. Day, J. Bassett, B. Bowler, S. Parminter, N. Bullard, M. Furr, N. Prentice, T. Robb, Bringing extensive reading into the classroom. pp. 10-21. Oxford: Oxford University Press. 
Day, R., \& Yamanaka, J. (2007). Cover to cover: Reading comprehension and fluency. Oxford: Oxford University Press.

Elghotmy, H. (2018). Using sheltered instruction strategies to develop EFL secondary stage students' reading comprehension skills. Studies in Curriculum and Instruction Journal, 231, 1-36.

Forrest-Pressley, G., MacKinnon, T. \& Waller, G. (2013). Metacognition, Cognition, and Human Performance. Instructional Practices. Vol.2, Academic Press.

Furr, M. (2011). Reading circles. In R. Day, J. Bassett, B. Bowler, S. Parminter, N. Bullard, M. Furr, N. Prentice, T. Robb, Bringing extensive reading into the classroom. pp. 63-74, Oxford: Oxford University Press.

Hill, D. (2008). Graded readers in English. ELT Journal, 62 (2), 184-204.

Hook, P., \& Jones, S. (2004). The importance of automaticity and fluency for efficient reading comprehension. IDA (The International Dyslexia Association) $55^{\text {th }}$ Annual conference, November 3-6, Philadelphia, PA.

Horst, M. (2005). Learning L2 vocabulary through extensive reading: A measurement study. The Canadian Modern Language Review, 61, 355382.

Hu, H., \& Nation, I. (2000). Unknown vocabulary density and reading comprehension. Reading in a Foreign Language, 13, 403-430.

Ibrahim, M. \& Ibrahim, Y. (2017). Communicative English language teaching in Egypt: Classroom practice and challenges. Issues in Educational Research, 27 (2), 285-313.

Irvin, J., Buehl, D., \& Klemp, R. (2007). Reading and the high school students. Pearson Education, Inc.

Iwahori, Y. (2008). Developing reading fluency: A study of extensive reading in EFL. Reading in a Foreign Language, 20(1), 70-91.

Kao, Y. (2017). An interesting read-aloud warm-up activity for freshman English. In M. Y. Li \&B. L. Reynolds (Eds.), Research into second language Chinese and English literacy instruction. $\mathrm{P}$

p. 25-50. Taiwan: National Central University Press \& Yuan-Liou Publishing Co., Ltd.

Kirin, W. (2010). Effects of extensive reading on students' writing ability in an EFL class. The Journal of Asia TEFL, 7(1), 285-308. 
Krashen, S. (2004). The power of reading: Insight from the research. Westport: Libraries Unlimited, The University of Michigan.

Krashen, S. (2013). Reading and vocabulary acquisition: Supporting evidence and some objections. Iranian Journal of Language Teaching Research, 1(1), 27-43.

Lao, C., \& Krashen, S. (2000). The impact of popular literature study on literacy development in EFL: More evidence for the power of reading. System, 28(2), 261-270.

Mermelstein, A. (2015). Improving EFL learners'writing through extensive reading. Reading in a Foreign Language, 27(2), 182-198.

Otto, W. \& White, S. (Ed.), (2014). Reading Expository Material. Academic Press.

Nation, I. (2001). Learning Vocabulary in Another Language. Cambridge: Cambridge University Press.

Nation, I. (2009). Teaching ESL/EFL reading and writing. New York, New York: Routledge.

Nation, I., \& Beglar, D. (2007). A vocabulary size test. The Language Teacher, 31(7), 9- 13.

Nation, I., \& Webb, S. (2011). Researching and analyzing vocabulary. Boston, MA: Heinle. Ntim, S. (2015). Comprehension skill differences between proficient and less proficient readers in word-to-text integration processes: Implications for interventions for students with reading problems. International Journal of Learning, Teaching and Educational Research, 13(3), 41-61.

Ostovar-Namaghi, S. (2018). Automaticity in reading: Teaching reading during-reading strategies. John Wiley \& Sons, Inc.

Reynolds, B. (2013). A web-based EFL writing environment as a bridge between academic advisers and junior researchers: A pilot study. British Journal of Educational Technology, 44(3).

Reynolds, B. (2015). A mixed-methods approach to investigating first- and second-language incidental vocabulary acquisition through the reading of fiction. Reading Research Quarterly, 50(1), 111-127.

Reynolds, B., \& Anderson, T. (2015). Extra-dimensional in-class communications: Action research exploring text chat support of faceto-face writing. Computers and Composition, 35, 52-64. 
Reynolds, B., \& Bai, Y. (2013). Does the freedom of reader choice affect second language incidental vocabulary acquisition? British Journal of Educational Technology, 44(2), 42-44.

Shih, Y., \& Reynolds, B. (2015). Teaching adolescents EFL by integrating think-pair-share and reading strategy instruction: A quasi-experimental study. RELC Journal, 46(3), 221- 235.

Shih, Y., Chern, C. \& Reynolds, B. (2018). Bringing extensive reading and reading strategies, Reading in a Foreign Language, 30 (1), 130-151.

Smith, K. (2011). Integrating one hour of in-school weekly SSR: Effects on proficiency and spelling. International Journal of Foreign Language Teaching, 7, 1-7.

Sun, L. (2011). A study of the effects of reciprocal teaching as a reading strategy instruction on metacognitive awareness, self-efficacy, and English reading comprehension of EFL junior high school students. Unpublished Ph.D. dissertation. La Sierra University, Riverside: California.

Takase, A. (2007). Japanese high school students' motivation for extensive L2 reading. Reading in a Foreign Language, 19, 1-18.

Taylor, A., Stevens, J., \& Asher, J. (2006). The effects of explicit reading strategy training on L2 reading comprehension. In J. M. Norris \& L. Ortega (Eds.), Synthesizing research on language learning and teaching. Pp. 213-244. Philadelphia: John Benjamins.

Tsai, C. (2000). Comprehension strategies used by technical college EFL students in Taiwan in comprehending English expository texts. Unpublished Ph.D. dissertation. University of Mississippi: Oxford, Mississippi.

Tzeng, O., \& Singer, H. (Eds.), (2017). Perception of Print: Reading Research in Experimental Psychology. Routledge.

Wolf, G. (2018). Developing reading automaticity and fluency: Revisiting what reading teachers know, putting confirmed research into current practice. Creative Education, 9, 838-855.

Yamashita, J. (2008). Extensive reading and development of different aspects of L2 Proficiency. System, 36, 661- 672. 